\title{
Framework for a Risk-Informed Groundwater Compliance Strategy for Corrective Action Unit 98: Frenchman Flat, Nevada National Security Site, Nye County, Nevada
}

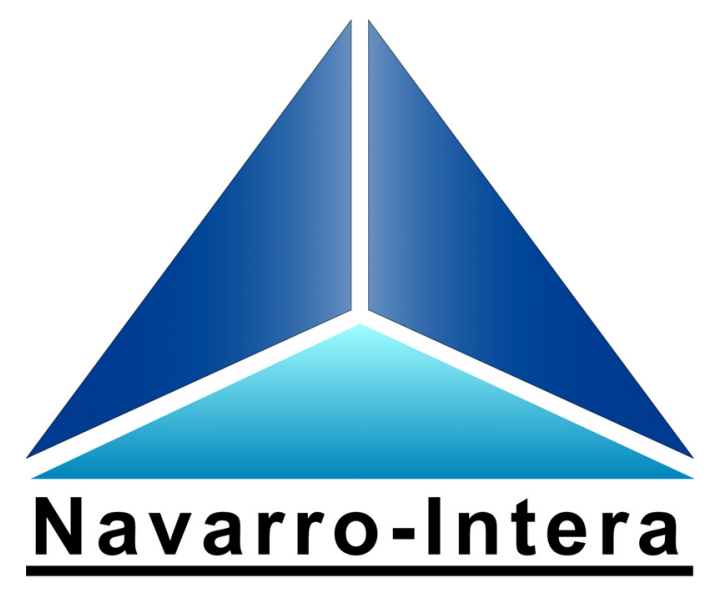

Revision No.: 1

September 2010 
Available for sale to the public from:

U.S. Department of Commerce

National Technical Information Service

5301 Shawnee Road

Alexandria, VA 22312

Telephone: 800.553 .6847

Fax: 703.605.6900

E-mail: orders@ntis.gov

Online Ordering: http://www.ntis.gov/help/ordermethods.aspx

Available electronically at http://www.osti.gov/bridge

Available for a processing fee to U.S. Department of Energy and its contractors, in paper, from:

\section{U.S. Department of Energy}

Office of Scientific and Technical Information

P.O. Box 62

Oak Ridge, TN 37831-0062

Phone: 865.576 .8401

Fax: 865.576.5728

Email: reports@adonis.osti.gov

Reference herein to any specific commercial product, process, or service by trade name, trademark, manufacturer, or otherwise, does not necessarily constitute or imply its endorsement, recommendation, or favoring by the United States Government or any agency thereof or its contractors or subcontractors. 


\section{Navarro-Intera}

FRAMEWORK FOR A RISK-INFORMED GROUNDWATER COMPLIANCE STRATEGY FOR CORRECTIVE ACTION UNIT 98: FRENCHMAN FLAT, NEVADA NATIONAL SECURITY SITE, NYE COUNTY, NEVADA

Revision No.: 1

September 2010

Navarro-Intera, LLC

c/o U.S. DOE

P.O. Box 98952

Las Vegas, NV 89193-8952

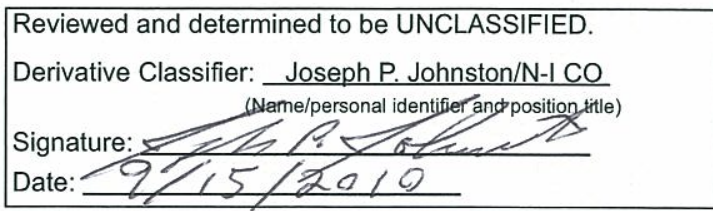

Prepared for U.S. Department of Energy under Contract No. DE-AC52-09NA28091.

Approved for public release; further dissemination unlimited. 
FRAMEWORK FOR A RISK-INFORMED GROUNDWATER COMPLIANCE STRATEGY FOR CORRECTIVE ACTION UNIT 98: FRENCHMAN FLAT, NEVADA NATIONAL SECURITY SITE, RYE COUNTY, NEVADA

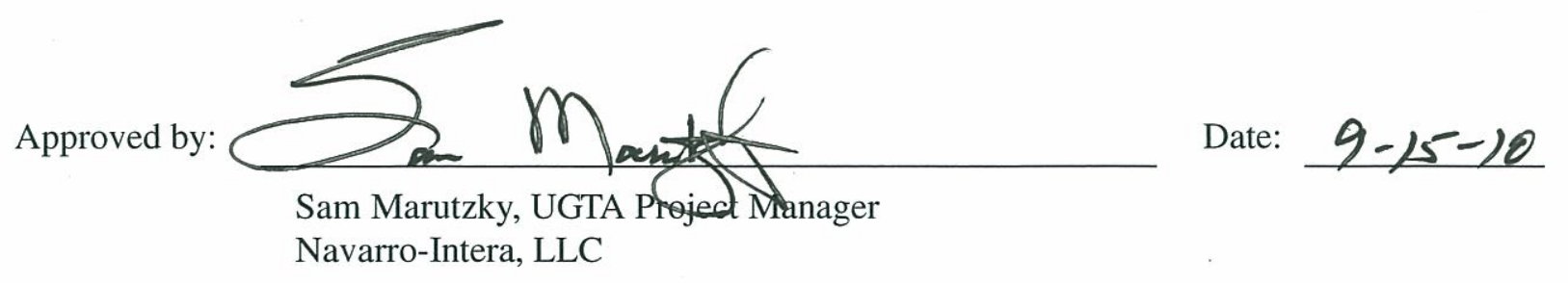




\section{TABLE OF CONTENTS}

List of Figures. . . . . . . . . . . . . . . . . . . . . . . . .

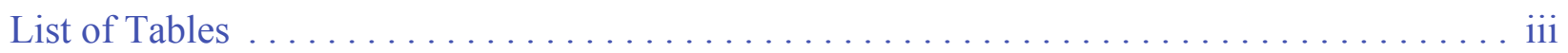

List of Acronyms and Abbreviations $\ldots \ldots \ldots \ldots \ldots \ldots \ldots \ldots \ldots \ldots \ldots \ldots \ldots \ldots \ldots \ldots$

$1.0 \quad$ Introduction. . . . . . . . . . . . . . . . . . . . . . .

$2.0 \quad$ Background. . . . . . . . . . . . . . . . . . . . . . . 2-1

$2.1 \quad$ Risk Assessment Overview . . . . . . . . . . . . . . . . . 2-1

2.2 Frenchman Flat CAU Risk Review Panel . . . . . . . . . . . . . . . 2-2

3.0 Potential Exposures to Site-Related Contamination. . . . . . . . . . . . . . . . 3-1

3.1 Current and Potential Future Land Use . . . . . . . . . . . . . . . . . 3-1

3.2 Contaminant Transport Modeling. . . . . . . . . . . . . . . 3-8

4.0 Safe Drinking Water Act Standards and Risk . . . . . . . . . . . . . . . . 4-1

$4.1 \quad$ Risks Associated with SDWA MCLs. . . . . . . . . . . . . . . . . 4-1

4.2 Establishing Contaminant/Compliance Boundaries

(MCL- versus Risk-Based Approaches) . . . . . . . . . . . . . . . . 4-1

$5.0 \quad$ Risk Characterization . . . . . . . . . . . . . . . . . . . . 5-1

5.1 Conceptual Site Model and Analytical Approach . . . . . . . . . . . 5-2

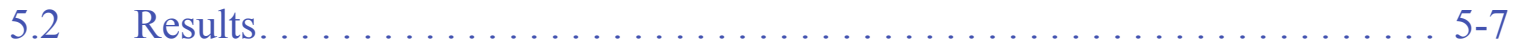

5.3 Probabilities for a Complete Exposure Scenario . . . . . . . . . . . 5-12

6.0 Conclusions. . . . . . . . . . . . . . . . . . . . . . .

$7.0 \quad$ References............................... 7 - $^{2}$

Appendix A - External Risk Review Panel Findings

Appendix B - UGTA Subproject Responses to External Risk Review Panel Findings 


\section{LIST OF FIGURES}

NUMBER

TITLE

PAGE

1-1 Nevada Test Site and Frenchman Flat CAU Location Map. . . . . . . . . . . . . 1-2

3-1 Land Use within the NTS and Surrounding the Frenchman Flat CAU . . . . . . . 3-2

3-2 Regional Land Use Surrounding the NTS . . . . . . . . . . . . . 3-3

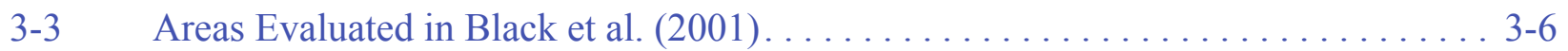

3-4 Composite Plot of Time-Cumulative Contaminant Boundaries for

All Alternative Transport Simulations for the Northern Testing Area. . . . . . . . . . 3-10

3-5 Map of the Offsite Plume Areas for the PIN STRIPE, MINUTE STEAK, and MILK SHAKE Underground Tests

for the Selected Contaminant Boundary Forecasts for the Northern

Testing Area of the Frenchman Flat CAU . . . . . . . . . . . . . . . . 3-11

5-1 Forecasted Radionuclide Concentrations Relative to SDWA Standards . . . . . . . 5-10

5-2 Drinking Water Risks for Forecasted Radionuclide Concentrations . . . . . . . . . 5-10

5-3 Summary of Fate and Transport Modeling Results Combined with Risk Results. . . 5-11 


\section{LIST OF TABLES}

NUMBER

3-1 Offsite Radionuclide Plume Areas and Concentrations . . . . . . . . . . . . . 3-12

4-1 Risks Associated with SDWA Standards . . . . . . . . . . . . . 4-2

5-1 Summary of Pathways Considered for Resident Farmer Scenario . . . . . . . . . . 5-2

5-2 Summary of Assumed Values Used in Resident Farmer Risk Calculations . . . . . . 5-3

5-3 Contaminant-Specific Assumptions Used in the Risk Calculations . . . . . . . . 5 5-6

5-4 Results of Risk Calculations for PIN STRIPE, MINUTE STEAK, and MILK SHAKE Contaminant Boundaries . . . . . . . . . . . . . 5-8

5-5 Summary of Pathway-Specific Contributions . . . . . . . . . . . . . 5-9

5-6 Parameters for $\mathrm{p}(\mathrm{IHI})$ Calculation for Offsite Groundwater Contamination . . . . . 5-14 


\section{LIST OF ACRONYMS AND ABBREVIATIONS}

\begin{tabular}{|c|c|}
\hline${ }^{3} \mathrm{H}$ & Tritium \\
\hline $\mathrm{C}$ & Carbon \\
\hline CAS & Corrective Action Site \\
\hline CAU & Corrective Action Unit \\
\hline $\mathrm{CEV}$ & Cumulative exceedance volume \\
\hline $\mathrm{Cl}$ & Chlorine \\
\hline $\mathrm{cm}^{3} / \mathrm{g}$ & Cubic centimeters per gram \\
\hline DoD & U.S. Department of Defense \\
\hline DOE & U.S. Department of Energy \\
\hline EPA & U.S. Environmental Protection Agency \\
\hline FFACO & Federal Facility Agreement and Consent Order \\
\hline $\mathrm{ft}$ & Foot \\
\hline g & Gram \\
\hline $\mathrm{g} / \mathrm{m}^{3}$ & Grams per cubic meter \\
\hline I & Iodine \\
\hline IHI & Inadvertent human intrusion \\
\hline $\mathrm{kg}$ & Kilogram \\
\hline $\mathrm{km}^{2}$ & Square kilometer \\
\hline $\mathrm{L}$ & Liter \\
\hline $\mathrm{m}$ & Meter \\
\hline MCL & Maximum contaminant level \\
\hline mrem & Millirem \\
\hline N/A & Not applicable \\
\hline NAD & North American Datum \\
\hline $\mathrm{NCP}$ & National Contingency Plan \\
\hline NNSA/NSO & $\begin{array}{l}\text { U.S. Department of Energy, National Nuclear Security Administration } \\
\text { Nevada Site Office }\end{array}$ \\
\hline NPDWR & National Primary Drinking Water Regulation \\
\hline NTS & Nevada Test Site \\
\hline $\mathrm{pCi} / \mathrm{L}$ & Picocuries per liter \\
\hline RMEI & Reasonably Maximally Exposed Individual \\
\hline
\end{tabular}




\section{LIST OF ACRONYMS AND ABBREVIATIONS (CONTINUED)}

RWMS Radioactive Waste Management Site

SDWA Safe Drinking Water Act

SME Subject matter expert

Tc Technetium

UGTA Underground Test Area

UTM Universal Transverse Mercator

$\mu \mathrm{g} / \mathrm{L} \quad$ Micrograms per liter 


\subsection{INTRODUCtION}

Corrective Action Unit (CAU) 98, Frenchman Flat, at the Nevada Test Site (NTS) was the location of ten underground nuclear tests between 1965 and 1971. As a result, radionuclides were released in the subsurface in the vicinity of the test cavities. Corrective Action Unit 98 and other CAUs at the NTS and offsite locations are being investigated in accordance with the Federal Facility Agreement and Consent Order (FFACO) with the State of Nevada (FFACO, 1996; as amended March 2010).

Note: This document was prepared before the NTS was renamed the Nevada National Security Site (August 23, 2010); thus, all references to the site herein remain NTS.

The Frenchman Flat CAU is one of five Underground Test Area (UGTA) CAUs at the NTS that are being evaluated as potential sources of local or regional impact to groundwater resources. For UGTA sites, including Frenchman Flat, contamination in and around the test cavities will not be remediated because it is technologically infeasible due to the depth of the test cavities (150 to 2,000 feet [ft] below ground surface) and the volume of contaminated groundwater at widely dispersed locations on the NTS. Instead, the compliance strategy for these sites is to model contaminant flow and transport, estimate the maximum spatial extent and volume of contaminated groundwater (over a period of 1,000 years), maintain institutional controls, and restrict access to potentially contaminated groundwater at areas where contaminants could migrate beyond the NTS boundaries (NNSA/NSO, 2006a). Figure 1-1 shows the location of Frenchman Flat in relation to other CAUs at the NTS.

The FFACO requires that contaminant boundaries be established based on groundwater transport modeling which will define areas containing water potentially unsafe for domestic and municipal use. The contaminant boundaries are based on forecasts of the spatial extent over a 1,000-year period of groundwater exceeding the Safe Drinking Water Act (SDWA) standards for radionuclides. A compliance boundary or boundaries will be negotiated based in part on the model forecasts of ensembles of contaminant boundaries. The compliance boundary can, but does not have to, coincide 


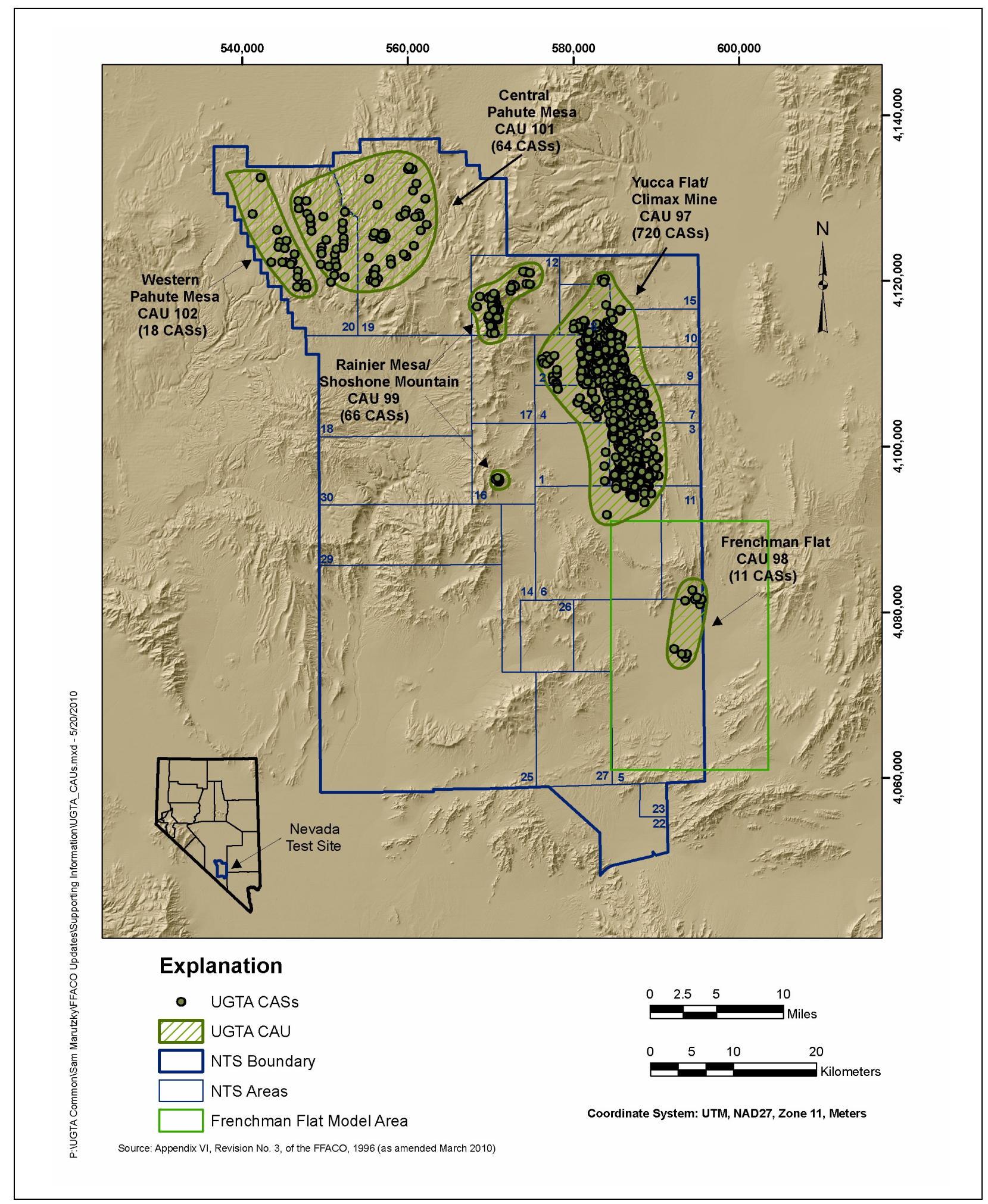

Figure 1-1

Nevada Test Site and Frenchman Flat CAU Location Map 
with predicted contaminant boundaries. Monitoring networks and institutional controls will be used in conjunction with contaminant transport modeling to ensure that the compliance boundary is protective of human health and the environment.

Given the range of radionuclides produced during underground testing and the complexity of the hydrogeologic setting, questions have been raised regarding the protectiveness and appropriateness of the UGTA groundwater strategy based solely on the SDWA. An external risk review panel was assembled to review previous studies conducted for Frenchman Flat and make recommendations on how risk assessment can be more fully integrated into the UGTA groundwater strategy (the panel's 2009 report is included as Appendix A). Recent groundwater transport modeling results show that some test-produced contamination has the potential to migrate beyond the NTS boundary at three CAUs: CAU 98, Frenchman Flat; CAU 101, Central Pahute Mesa; and CAU 102, Western Pahute Mesa (SNJV, 2009; NNES, 2010).

The original scope of this effort was to determine whether the SDWA radionuclide standards specified in the FFACO are fully protective, address issues raised by the risk panel, and examine potential future offsite risks. After further consideration, however, the emphasis for this report was placed on comparing risk estimates for the Frenchman Flat CAU with the protection requirements of the SDWA. Resolution of all the risk panel findings was not attempted in this paper. 


\subsection{BACKGROUND}

This section presents an overview of risk assessment principles that apply generally and those that are more specific to the Frenchman Flat CAU and the findings of the risk panel.

\section{$2.1 \quad$ Risk Assessment Overview}

The basic premise of risk assessment is that a receptor (person, animal) comes in contact with, or is exposed to, a contaminated medium (water, soil, air). Effects of this exposure are dependent on the length, frequency, and amount of exposure (e.g., one time, every day; large or small volume); the manner in which the contact occurs (e.g., ingested, inhaled, or absorbed through the skin); and the toxicity of the contaminant. For carcinogenic contaminants, which include all radionuclides, risk calculations provide an estimation of the statistical likelihood of contracting cancer. In accordance with the U.S. Environmental Protection Agency's (EPA) risk assessment methodology, results are expressed in terms of estimated excess cancer risks above those considered "normal" for the general population. The "acceptable" range of excess cancer risks from exposure to environmental media is 1 in $1,000,000\left(1 \times 10^{-6}\right)$ to 1 in $10,000\left(1 \times 10^{-4}\right){ }^{1}$

A site-wide NTS risk assessment was completed based on the regional groundwater modeling results (DOE/NV, 1997). Potential risks associated with exposures to tritium were evaluated for both human and ecological receptors. The estimated risks to ecological receptors were considered acceptable, as toxicity-based benchmarks were exceeded in a limited number of scenarios using conservative transport, exposure, and toxicity assumptions. Furthermore, and perhaps most important, a complete exposure pathway to ecological resources/receptors in the NTS area is unlikely given the depth of groundwater and lack of surface springs downgradient of areas of contaminated groundwater

1. In its final National Contingency Plan (NCP) for Superfund site remediation, EPA codified a range of acceptable risks $\left(1 \times 10^{-6}\right.$ to $\left.1 \times 10^{-4}\right)$ as a basis for remediation of Superfund sites; this rule has since been applied more globally to other sites, including sites controlled by the U.S. Department of Energy (DOE) (CFR, 2009c). 
(except for the Pahute Mesa CAUs). Therefore, ecological risks at Frenchman Flat were not considered further.

For potential future human receptors, maximum modeled concentrations were used for multiple pathways using bounding assumptions. Risks were calculated for exposures at the site boundary. Acceptable risks were only exceeded for the modeled plume when tritium exceeded the SDWA maximum contaminant level (MCL) at the site boundary. This default approach may not be appropriate for the NTS based on the following:

- The nature of radioactive contamination

- The existing institutional control of the site

- The isolation of the site

- The considerable depth to groundwater

- The limited favorable surface features that would draw a homesteader to this area

The risk panel considered these issues in its evaluation. This paper estimates future hypothetical risks to potential human receptors and compares these risks with the protection provided by the radiological standards of the SDWA.

\subsection{Frenchman Flat CAU Risk Review Panel}

The risk panel's 2009 report reviewed the risk basis for the Frenchman Flat CAU strategy (Appendix A). The risk panel's objectives were to determine (1) whether risk-based concepts had been adequately incorporated into the project strategy so that it was appropriate to proceed to the next phase of CAU activity, and (2) if DOE could explore other risk scenarios, what they should be.

The report includes results of the panel's evaluation. This paper was developed in response to the recommendations of the risk panel contained in the report. This report is not a formal risk assessment; instead, its primary objective is to provide comparisons between the protections provided by the radiological standards of the SDWA and risk-based approaches using dose/scenario calculations that implement current institutional and land use policies of the NTS. Given the limited scope of this work, much of the required information for the risk calculations is modified and/or adapted from existing studies referenced in this paper. 
Some of the observations, suggestions, and concerns of the panel were generic to the use of SDWA standards for defining contaminant boundaries. These included the following:

- A combination of SDWA categories can "swamp the ability of the SDWA to protect public health and the environment."

- National Primary Drinking Water Regulation (NPDWR) ${ }^{2}$ terminology is not harmonious or easily interpreted by stakeholders, particularly members of the general public.

- Concern that SDWA standards for radionuclides are based on outdated science (with the exception of uranium).

- The MCLs should be compared to risk equivalents for a residential water ingestion scenario.

Other more site-specific comments include the following:

- The unique characteristics of the Frenchman Flat CAU may preclude any future public exposure to contaminated groundwater, therefore resulting in zero risk; this should be factored into a risk evaluation.

- Once transport model outputs are determined to be adequate, risk calculations can be performed, particularly for areas outside the boundary and/or areas without institutional controls for purposes of risk communication.

- The SDWA standards may be useful to identify what effect the risk equivalent concentrations may have on contaminant (and ultimately, compliance) boundaries for risk communication purposes.

- The SDWA approach may be supplemented with site-specific risk assessment.

- Uncertainties associated with establishment of contaminant boundaries, including any associated risk analysis, should be communicated in a manner that could be understood by the general public.

The emphasis of this report is on comparing risk estimates for the Frenchman Flat CAU with the protection requirements of the SDWA; no attempt is made to resolve all of the findings of the risk panel. Section 3.0 discusses issues related to potential contaminant exposures. The issues discussed are similar to those addressed in the exposure assessment of a traditional risk assessment, which include contaminant identification and potential exposure locations. Section 4.0 discusses

2. Developed as a requirement of the SDWA, NPDWRs for radionuclides are more commonly referred to as SDWA standards or MCLs for radionuclides. 
site-related contaminants in terms of risk and drinking water standards. Section 5.0 presents the site-specific risk calculations based on transport model output for Frenchman Flat, with emphasis on areas forecast to have offsite contaminant migration. Conclusions are presented in Section 6.0. 


\subsection{Potential Exposures to Site-ReLATED CONTAMINATION}

No complete pathways from contaminated groundwater to the surface currently exist at the Frenchman Flat CAU, nor are any anticipated in the 1,000-year interval. To evaluate risks, a complete pathway must be assumed to exist. Two key observations of the risk panel were that the remoteness and government control of the NTS impact the types of viable pathways and that the likelihood of these pathways being complete increases over time with the increased uncertainty associated with extrapolating from current conditions. Because it is assumed that the NTS will remain under government control and that access to contaminated water can be prevented within the NTS boundaries, the UGTA strategy focuses on those areas where offsite migration of contamination is considered most likely. These areas are determined based on transport modeling results for an ensemble of contaminant boundaries that incorporate statistical and structural uncertainty. This allows modeling and monitoring to be directed toward areas where offsite exposures may occur. The portions of contaminant boundaries that remain on the NTS would be less important than those that are located beyond the NTS boundary. This section describes the viable exposure scenarios that may occur over time and provides an overview of the contaminant transport model used to estimate future contaminant concentrations.

\subsection{Current and Potential Future Land Use}

The NTS covers about 1,375 square miles of land under the jurisdiction of the DOE. The area within 50 miles of the NTS is predominantly rural (NNSA/NSO, 2006a). The NTS is surrounded on all sides by government-owned lands: the Nevada Test and Training Range to the north, east, and west; and Bureau of Land Management lands on the south and southwest (NNSA/NSO, 2006a).

Figures 3-1 and 3-2 show the land use within the NTS and in surrounding areas. The administrative community of Mercury is located on the southeastern portion of the NTS and houses temporary workers for temporary periods. There are no permanent residents in Mercury or within the NTS. The closest towns are Indian Springs and Amargosa Valley (Figure 3-2), the latter an agricultural area 


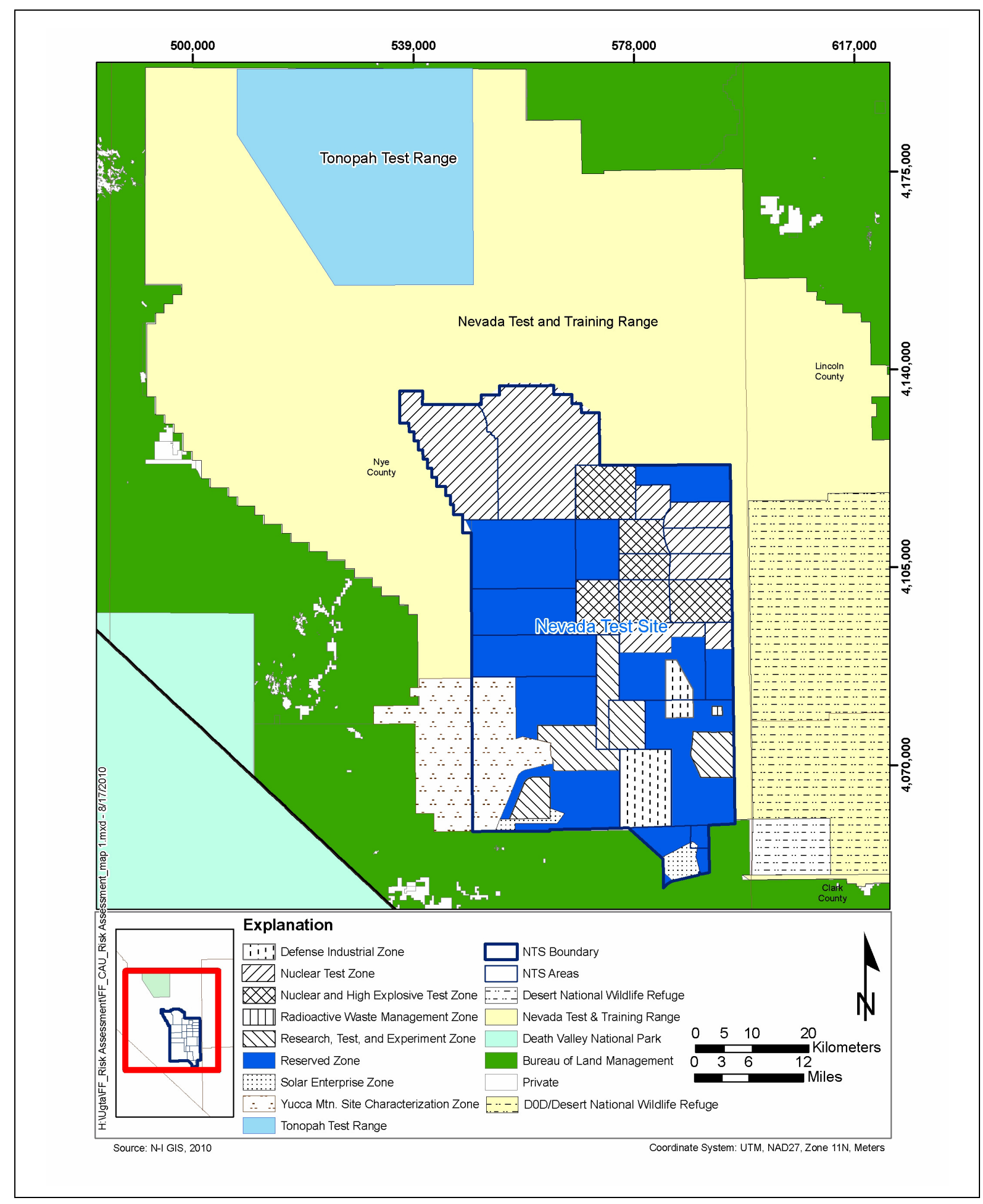

Figure 3-1

Land Use within the NTS and Surrounding the Frenchman Flat CAU 


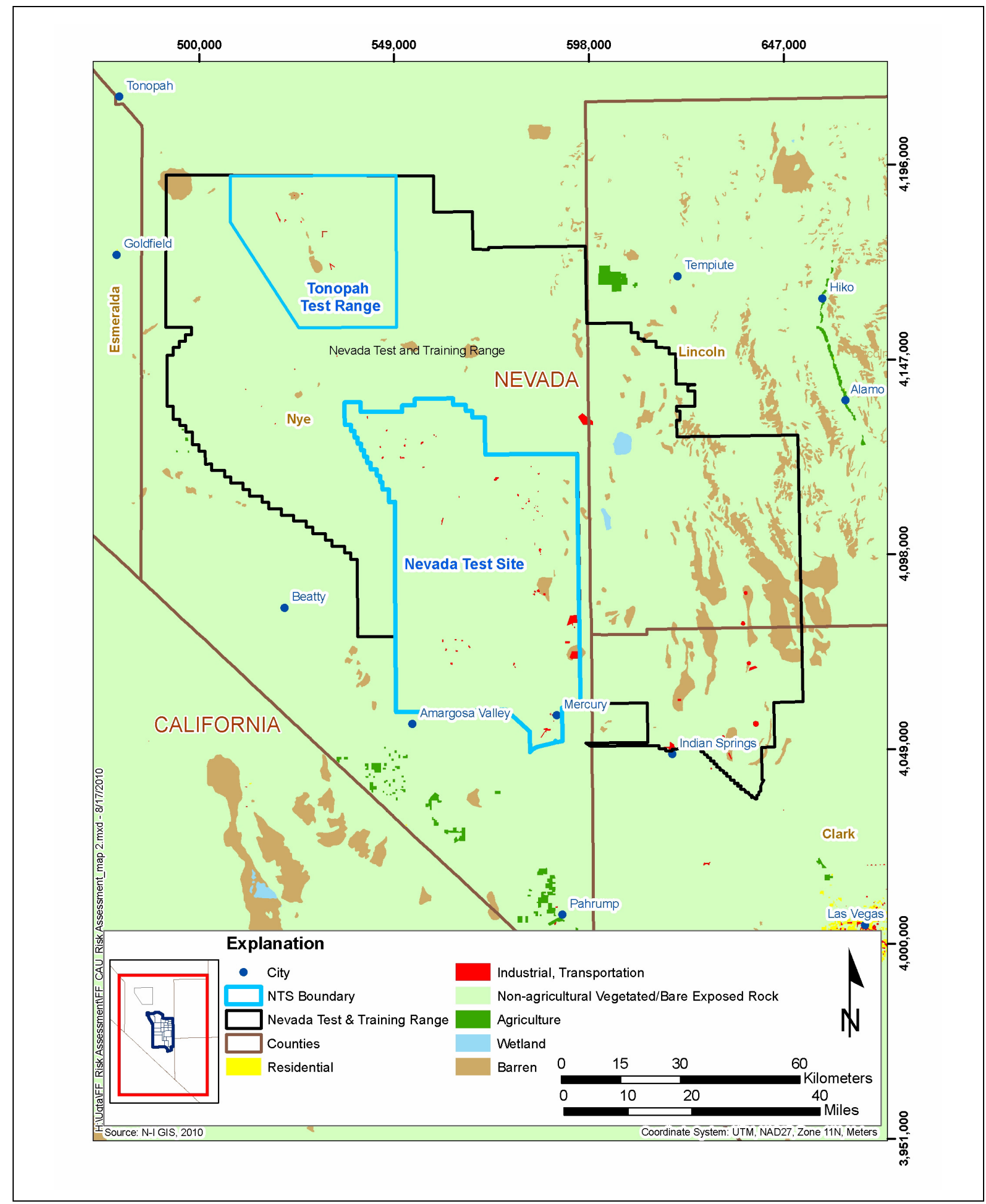

Figure 3-2

Regional Land Use Surrounding the NTS 
with a population of about 1,000 (NNSA/NSO, 2006a). Both communities are located outside the southern NTS boundary, well beyond the extent of contaminant boundaries forecasted for the Frenchman Flat CAU (NNES, 2010).

Uses of the NTS are not anticipated to change in the foreseeable future. However, as required by DOE Order 435.1 (DOE, 2001), as part of the performance assessment, an expert panel assessed the probability of inadvertent human intrusion (IHI) into deep and intermediate buried low-level radioactive waste at the NTS (including Frenchman Flat). This evaluation, titled Assessing the Probability of Inadvertent Human Intrusion at the Nevada Test Site Radioactive Waste Management Sites (Black et al., 2001), developed scenarios for IHI and estimated probabilities of intrusion into buried radioactive waste.

Black et al. (2001) defines an IHI as an individual who unintentionally breaches buried waste during the regulatory compliance period after closure. In the context of the Frenchman Flat CAU, the intrusion mechanism of concern is exploratory drilling for groundwater, and "inadvertent" is the operative term. When intrusion is inadvertent, the intruder does not recognize that a hazardous situation exists - a circumstance that might hold true for areas accessible to the public, such as those in Amargosa Valley. However, appropriate institutional controls (and the inherent dissemination of information and requisite protections) are in place at the NTS and will be so in perpetuity. The institutional controls may also apply to the federal land east of the NTS owned by the U.S. Department of Defense (DoD), which encompasses the eastern and southernmost extent of forecasted contaminant boundaries.

The IHI probability is dependent upon a loss of institutional control of the NTS and the way in which an IHI would settle in a remote alluvial valley. Black et al. (2001) developed probability distributions for the time to loss of institutional controls (both active and passive controls) and identified a number of possible credible scenarios besides the standard homesteader scenario. Consequently, the assessment included both the default independent homesteader scenario and community scenarios. Community scenarios considered include development of community settlements in Frenchman Flat or Yucca Flat, as well as the development or growth of nearby communities that causes Frenchman Flat or Yucca Flat to be settled by "commuter homesteaders" without development of an actual community base within either Flat. 
In general, the homesteader scenario assumes independent homesteading with no shared resources and at least one well per household. A community in Frenchman Flat or Yucca Flat, by contrast, assumes that the community has an infrastructure that facilitates sharing of resources and that water is supplied through a community production well system. The remaining scenarios are hybrids, assuming "homesteading" in Frenchman Flat and Yucca Flat by "commuters" from nearby communities or Las Vegas. These community scenarios were expected to be driven by current population trends that indicate population expansion in Las Vegas and surrounding areas. Figure 3-3 shows the areas evaluated in Black et al. (2001).

A number of possible intrusion scenarios were identified in workshop discussions between stakeholders and subject matter experts (SMEs) representing a variety of expertise in physical and social sciences. The SMEs were provided with complete freedom to discuss and revise the scenarios as necessary. This process resulted in acceptance of the standard homesteader scenario and refinement of the preliminary community scenario. Three separate community scenarios were identified by the SMEs:

1. The Base Community Scenario-A small community is located in the alluvial basins of Frenchman Flat or Yucca Flat.

2. The Jackass Flats Scenario - A small community is located in Mercury, Jackass Flats, or another nearby area, allowing for "commuter homesteaders" living in Frenchman Flat or Yucca Flat.

3. The Las Vegas Expansion Scenario-Urban expansion of Las Vegas north up the valley corridor and into the alluvial basins of the NTS allows for "commuter homesteaders" in Frenchman Flat or Yucca Flat.

The probability values calculated based on the SME input and the modeling process suggested that the probability of IHI is very small. The possible exception was for Frenchman Flat under the Jackass Flats scenario. The scenario probability was approximately 11 percent. Several important observations from the scenario results are as follows:

- The Jackass Flats scenario resulted in the highest probabilities, primarily because of the proportion of time that the potential for "commuter homesteading" was assumed by the SMEs (i.e., 50 percent of the evaluation period of 10,000 years for the Jackass Flats scenario, versus 0.25 to 1 percent and 10 percent for the Base Community and Las Vegas Expansion scenarios, respectively). 


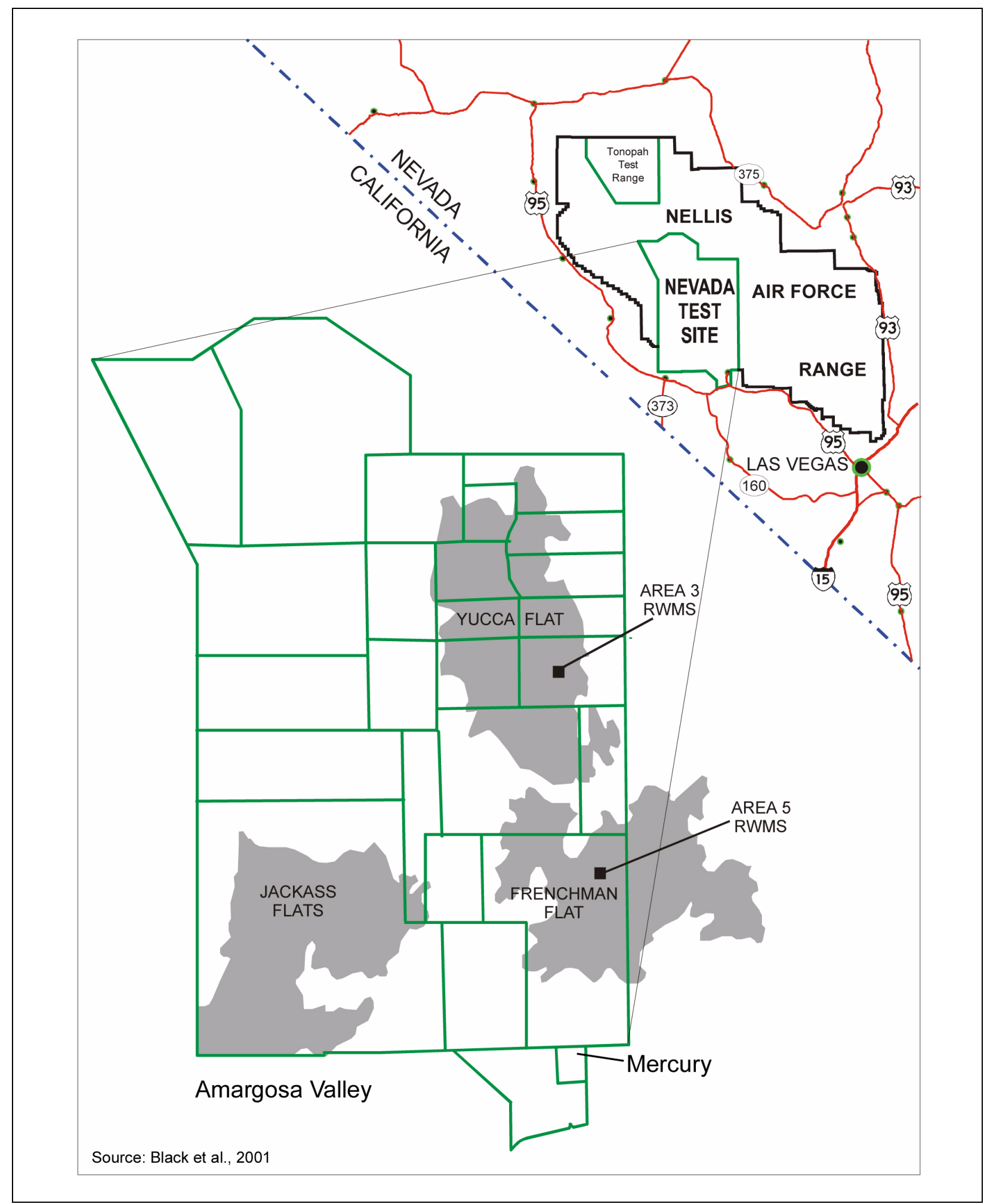

Figure 3-3

Areas Evaluated in Black et al. (2001) 
- The probabilities for the Yucca Flat community scenarios were consistently an order of magnitude or more lower than those for the Frenchman Flat community scenarios.

- A change in the size of the waste footprint can have a pronounced effect on the IHI probability.

- The IHI probabilities were assessed for 10,000 years, whereas the compliance interval for the UGTA requirements is 1,000 years.

Among the four intrusion scenarios considered, the Jackass Flats scenario is by far the most dominant scenario, i.e., the probabilities estimated are much greater for the Jackass Flats scenario than for the other scenarios. The Jackass Flats scenario is so dominant that excluding the other scenarios from the calculation of the overall (combined) probability of IHI has little impact on the result (less than 1 percent). The Jackass Flats scenario, by itself, effectively controls the combined probability of IHI. Consequently, the reported overall probabilities of IHI conditioned on loss of management controls are the same as those reported for the Jackass Flats scenario: 11 percent for Frenchman Flat and 0.65 percent for Yucca Flat. This paper assumes that the footprint of an offsite contaminant plume can be treated in the same manner as the waste footprint used in Black et al. (2001).

Although Black et al. (2001) focused on buried wastes located in a static environment, the results can be extrapolated to surface areas with subsurface groundwater contamination. Of greatest importance is the potential offsite groundwater contamination that may migrate beyond current management controls for the NTS. As such, observations from Black et al. (2001) lead to the following assumptions for assessing future scenarios of public access to contaminated groundwater:

1. Public access to surface land above contaminated groundwater will not result in radiological exposure. Transient and/or open range land use scenarios are not applicable.

2. The most likely well drilling scenarios involve a homesteader and/or small community where a water well is drilled for drinking water and/or for small-scale irrigation or livestock use.

3. Active institutional controls at the NTS are expected to be 100 percent effective for prevention of drilling scenarios. Inadvertent surface access to the NTS may be possible, but drilling to groundwater requires mobilization of a drilling rig and logistical support, which are readily detected and prevented.

With no public access to contaminated groundwater on the NTS, the risk of exposure is negligible. The potential future risk to the public is for contaminated groundwater migrating over the next 1,000 years off the controlled boundaries of the NTS. 


\subsection{Contaminant Transport Modeling}

Frenchman Flat groundwater modeling was performed to evaluate multiple alternative flow models for the Frenchman Flat physiographic basin, which is a subset of the Death Valley Regional Flow System. The models were developed by determining the direction and magnitude of groundwater fluxes and quantifying uncertainties in the hydrogeological setting, recharge, and parameters controlling groundwater flux (SNJV, 2006). Uncertainties in the flow model include both parametric and conceptual uncertainties, and multiple sets of flow models were calibrated. Once the flow models were satisfactorily completed, probabilistic transport simulations were added using multiple flow velocities and directions to assess the migration of radionuclides away from the test cavities and establish the output data used to forecast the ensembles of contaminant boundaries for each test.

Site geology and hydrogeology are summarized in the groundwater flow and transport documents for Frenchman Flat (SNJV, 2006; NNES, 2010). The Phase II transport modeling shows that five radionuclides, carbon-14 $\left({ }^{14} \mathrm{C}\right)$, chlorine-36 $\left({ }^{36} \mathrm{Cl}\right)$, tritium $\left({ }^{3} \mathrm{H}\right)$, iodine-129 $\left({ }^{129} \mathrm{I}\right)$, and technetium-99 $\left({ }^{99} \mathrm{Tc}\right)$, have the greatest control on the contaminant boundary forecasts completed for the Frenchman Flat transport simulations (NNES, 2010). These radionuclides are conservative (non-sorbing) species released in the exchange volume surrounding an underground test and immediately available for migration in the groundwater. Therefore, they can be indicator radionuclides for identifying the leading edge of contaminant migration consistent with migration of radionuclides away from test cavities and off the controlled boundaries of the NTS. As such, the risk characterization presented in the following section focuses on this suite of radionuclides.

Although contaminant transport modeling was conducted for all ten underground test sites at Frenchman Flat, the potential for offsite contaminant migration was indicated for only three test sites located in the northern test area: PIN STRIPE, MINUTE STEAK, and MILK SHAKE (NNES, 2010). The transport modeling was used to determine the contaminant boundaries for each of the tests.

The FFACO defines the outer boundary of the contaminant boundary as encompassing the region where there is a 5 percent or greater likelihood that contaminants exceed the SDWA regulatory standards. Simulation modeling of contaminant transport is used to forecast the location of contaminant boundaries within 1,000 years and must show the $95^{\text {th }}$ percentile of the model 
results (boundary outside of which only 5 percent or less of the simulations exceed the SDWA standards). Performing Monte Carlo simulations using the uncertainty distributions for the various model input parameters provides the transport model results from which such probabilities of occurrence of contaminated groundwater can be computed (NNES, 2010).

The contaminant boundaries are established by determining whether any of the following standards are exceeded in each model element during each model realization and integrating the results for all realizations:

- 15 picocuries per liter $(\mathrm{pCi} / \mathrm{L})$ gross alpha

- 30 micrograms per liter $(\mu \mathrm{g} / \mathrm{L})$ uranium

- 4 millirem (mrem) for the sum of all modeled beta/photon particles

If any of the standards was exceeded for a given realization, an exceedance count of 1 was added for that location. The total number of counts for each element was divided by the total number of realizations. If a value of 0.05 or higher was obtained, the element was included within the contaminant boundary. Illustrations of the contaminant boundary can be made in two ways: time-cumulative and time-specific probability maps. The time-specific probability maps show this value at a given time, whereas the time-cumulative probability maps show the maximum of this value at any of the times analyzed over the 1,000 years simulated. The contaminant boundary map can be difficult to characterize quantitatively because it represents a spatial geometry (surface projection of a volume of contaminated groundwater).

A metric more amenable to quantitative analysis, the time-cumulative exceedance volume (CEV) was developed. The CEV is defined as the total volume of all elements exceeding the SDWA standards (CFR, 2009b) at any time within a 1,000-year interval from the time of source release based on the Monte Carlo simulations (NNES, 2010). When the CEV is combined over all transport model results, a cumulative probability distribution of the exceedance volume is formed.

Frenchman Flat modeling studies of future contaminant transport forecast offsite contaminant migration for the PIN STRIPE, MINUTE STEAK, and MILK SHAKE underground tests in the northern test area. Multiple contaminant boundaries for these three tests with alternative combinations of hydrostratigraphic framework models, recharge, and boundary flux show off-NTS migration for some but not all model forecasts (NNES, 2010, Section 10). Figure 3-4 shows 


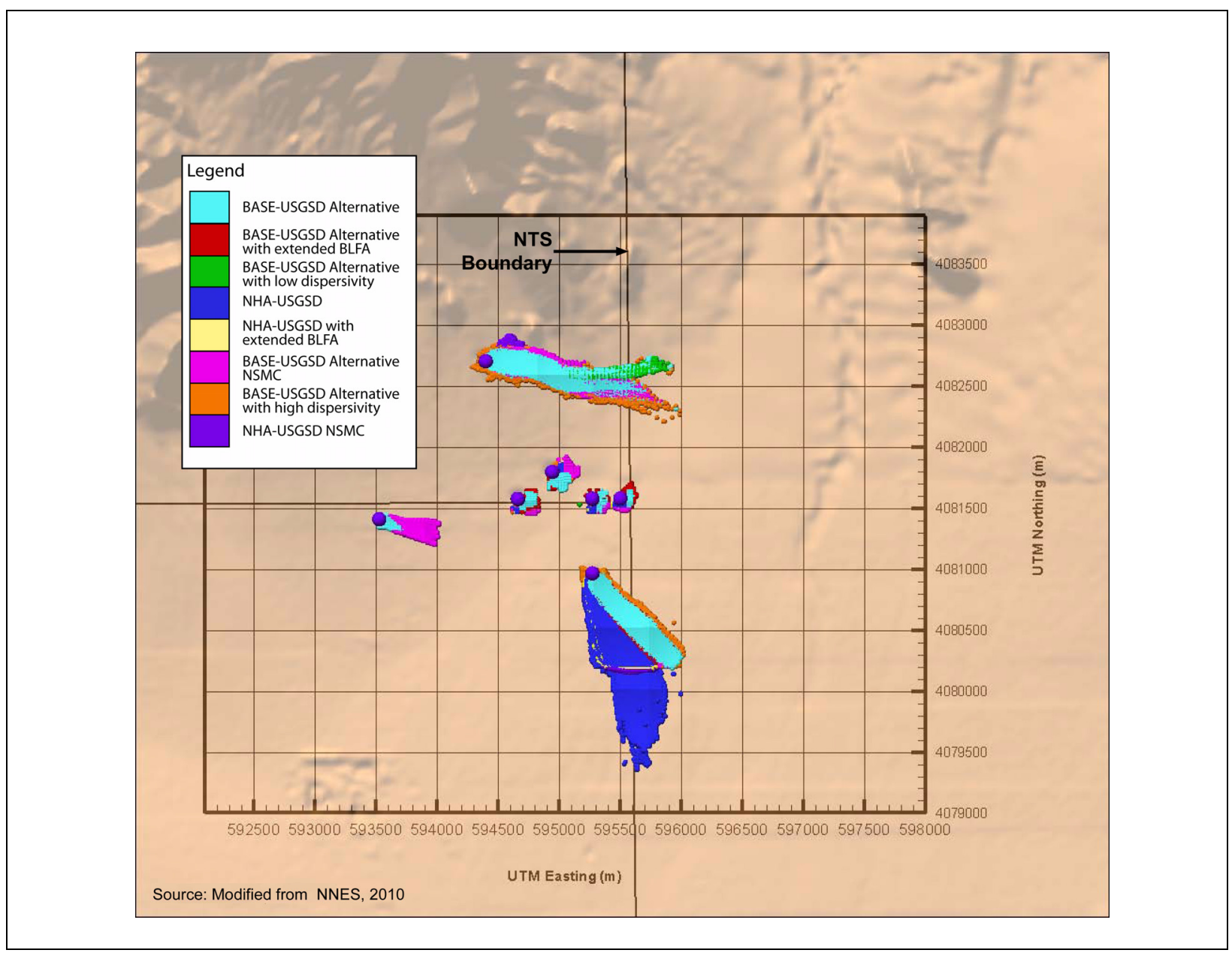

Figure 3-4

Composite Plot of Time-Cumulative Contaminant Boundaries for All Alternative Transport Simulations for the Northern Testing Area

a composite plot of the time-cumulative contaminant boundaries for all alternative transport simulations for the northern testing area, i.e., this figure shows the entire contaminant plume area for the transport simulations. As discussed in the transport model report (NNES, 2010), except for some variability for the MILK SHAKE test, the direction of transport is similar in all cases modeled, whereas travel distance varies significantly.

Figure 3-5 plots the offsite plume areas for the PIN STRIPE, MINUTE STEAK, and MILK SHAKE underground tests for the selected contaminant boundary forecasts and the probability of exceeding SDWA standards. In this figure, the selected contaminant boundaries for the dose/risk calculations are bounding (i.e., representing maximum offsite plume areas) from the alternative transport 


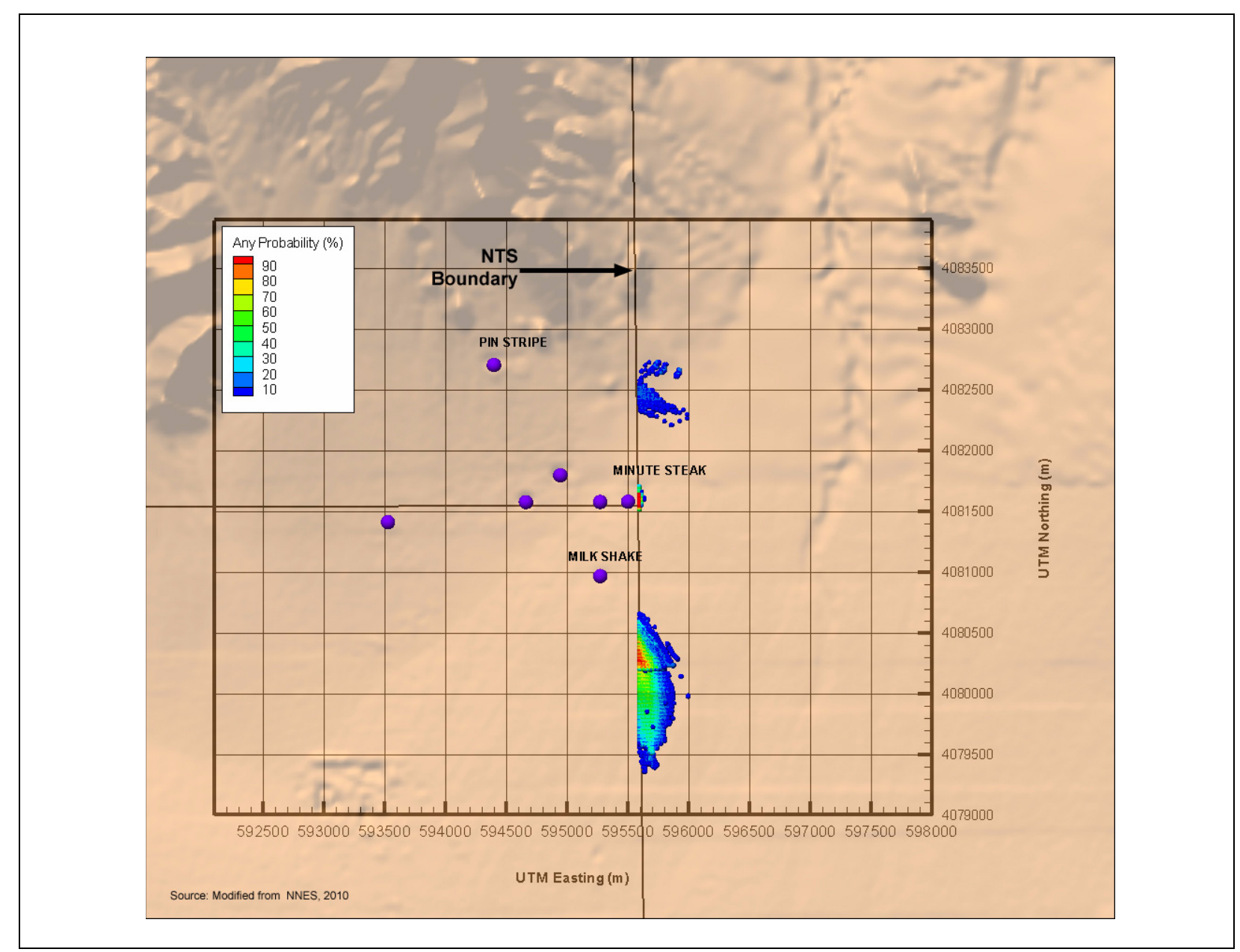

\section{Map of the Offsite Plume Areas for the PIN STRIPE, MINUTE STEAK, and MILK SHAKE Underground Tests for the Selected Contaminant Boundary Forecasts for the Northern Testing Area of the Frenchman Flat CAU}

simulations. For each of the offsite plumes shown on Figure 3-5, data from the transport modeling studies were extracted to establish the following:

1. The plume area extending outside the eastern boundary of the NTS in Frenchman Flat contained within the FFACO-defined contaminant boundary.

2. The time-maximum $\left(1,000\right.$ years) radionuclide concentrations of ${ }^{14} \mathrm{C},{ }^{36} \mathrm{Cl},{ }^{3} \mathrm{H},{ }^{129} \mathrm{I}$, and ${ }^{99} \mathrm{Tc}$ averaged over the volume of each off-NTS contaminant plume. The data were derived by post-processing the output data from the Monte Carlo transport simulations (NNES, 2010).

Table 3-1 lists the underground tests, the offsite plume areas, and the radionuclide concentrations in the offsite plume areas for the five radionuclides; the SDWA standards are provided for comparison. 
Table 3-1

Offsite Radionuclide Plume Areas and Concentrations

\begin{tabular}{||c|c|c|c|c|c|c||}
\hline Test & $\begin{array}{c}\text { Offsite } \\
\text { Plume Area } \\
\left(\mathbf{m}^{2}\right)\end{array}$ & $\begin{array}{c}{ }^{14} \mathbf{C} \\
(\mathbf{p C i} / \mathbf{L})\end{array}$ & $\begin{array}{c}{ }^{36} \mathbf{C l} \\
(\mathbf{p C i} / \mathbf{L})\end{array}$ & $\begin{array}{c}{ }^{3} \mathbf{H} \\
(\mathbf{p C i} / \mathbf{L})\end{array}$ & $\begin{array}{c}{ }^{129} \\
\mathbf{( p C i / L )}\end{array}$ & $\begin{array}{c}{ }^{99} \mathbf{T} \\
(\mathbf{p C i} / \mathbf{L})\end{array}$ \\
\hline \hline PIN STRIPE & 99,542 & $5.1 \mathrm{E}+02$ & $4.4 \mathrm{E}+01$ & $1.2 \mathrm{E}+03$ & $2.8 \mathrm{E}-02$ & $2.9 \mathrm{E}+00$ \\
\hline MINUTE STEAK & 11,688 & $6.5 \mathrm{E}+03$ & $5.4 \mathrm{E}+02$ & $5.2 \mathrm{E}+05$ & $3.1 \mathrm{E}-01$ & $3.9 \mathrm{E}+01$ \\
\hline MILK SHAKE & 291,496 & $1.0 \mathrm{E}+03$ & $1.1 \mathrm{E}+02$ & $5.0 \mathrm{E}+01$ & $7.3 \mathrm{E}-02$ & $7.5 \mathrm{E}+00$ \\
\hline SDWA MCLs & N/A & $2.0 \mathrm{E}+03$ & $7.0 \mathrm{E}+01$ & $2.0 \mathrm{E}+04$ & $1.0 \mathrm{E}+00$ & $9.0 \mathrm{E}+02$ \\
\hline
\end{tabular}

Values in red indicate that the offsite forecasted time-maximum concentration exceeds the corresponding SDWA standard. N/A = Not applicable 


\subsection{Safe Drinking Water Act Standards and RISK}

This section addresses issues raised by the risk panel regarding application of the SDWA standards for establishing the contaminant boundary. It is understood that the UGTA Subproject is bound by the FFACO agreements to use the SDWA standards.

\subsection{Risks Associated with SDWA MCLs}

As discussed in Section 3.0, the Phase II transport modeling indicated that a small subset of contaminants drives the contaminant boundary during the 1,000-year period (NNES, 2010). These species include ${ }^{14} \mathrm{C},{ }^{36} \mathrm{Cl},{ }^{3} \mathrm{H},{ }^{129} \mathrm{I}$, and ${ }^{99} \mathrm{Tc}$, all of which are beta/photon emitters. Because modeling results indicate that alpha emitters and uranium are inconsequential at Frenchman Flat (in terms of defining the contaminant boundary), they are not addressed quantitatively in this report. Table 4-1 presents estimated risks based on the SDWA concentrations for the driving subset of radionuclides. Risks were calculated using default conservative assumptions recommended by the risk panel: a drinking water ingestion rate of 2 liters (L) per day, 365 days per year, for a 70-year (i.e., lifetime) exposure duration (see Appendix A, Section 5.5, Recommendation \#4). To yield risk estimates more comparable to standard EPA risk assessment guidance, risks based on a 30-year exposure duration also were calculated.

As shown in Table 4-1, with the exception of ${ }^{129}$ I, SDWA concentrations slightly exceed a $10^{-4}$ cancer risk for all species when a 70-year exposure duration is assumed. This is not the case when a 30-year exposure duration is assumed (e.g., as applied in ANL, 2001). For all constituents, the latter assumption yields risk estimates that are within a $10^{-6}$ to $10^{-4}$ risk range.

\subsection{Establishing Contaminant/Compliance Boundaries (MCL- versus Risk-Based Approaches)}

The FFACO requires that contaminant boundaries be established based on SDWA standards. Inherent in the UGTA strategy is the assumption that exposure to contamination has a probability of 1 (100 percent chance). The assumptions and risks associated with that exposure were used to 
Table 4-1

Risks Associated with SDWA Standards

\begin{tabular}{|c|c|c|c|c|}
\hline Radionuclide & $\begin{array}{l}\text { SDWA } \\
\text { Concentration } \\
(p C i / L)^{a}\end{array}$ & $\begin{array}{c}\text { SDWA } \\
\text { Risk } \\
(70-y r / 30-y r)^{b}\end{array}$ & $\begin{array}{l}\text { Groundwater Concentration } \\
\text { Corresponding to } 10^{-4} \text { Risk, } \\
\text { pCi/L (70-yr/30-yr) }{ }^{b}\end{array}$ & $\begin{array}{l}\text { Slope Factor } \\
\left(\text { Risk/pCi) }{ }^{c}\right.\end{array}$ \\
\hline${ }^{{ }^{14} \mathrm{C}}$ & 2,000 & 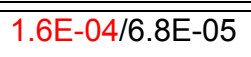 & $\overline{11,260 / 2,950}$ & $\overline{c 1.55 \mathrm{E}-12}$ \\
\hline${ }^{36} \mathrm{Cl}$ & 700 & 1.2E-04/5.1E-05 & $590 / 1,380$ & 3.30E-12 \\
\hline${ }^{3} \mathrm{H}$ & 20,000 & 1.1E-04/4.9E-05 & $13,590 / 31,710$ & $1.12 \mathrm{E}-13$ \\
\hline 129 & 1 & 7.6E-06/3.2E-06 & $710 / 1,660$ & $1.48 \mathrm{E}-10$ \\
\hline${ }^{99} \mathrm{TC}$ & 900 & 1.3E-04/5.4E-05 & $13 / 31$ & $2.75 \mathrm{E}-12$ \\
\hline
\end{tabular}

a Based on 4 mrem/year

${ }^{b}$ Risks were estimated using SDWA concentrations and the slope factors listed above, and assuming an ingestion rate of $2 \mathrm{~L}$ per day, 365 days per year, for exposure durations of 70 years (essentially upper bound) and 30 years (standard EPA, Argonne National Laboratory default). Groundwater concentrations that would yield a $10^{-4}$ cancer risk using these assumptions are listed in the fourth column (rounded).

c Water ingestion slope factor from Federal Guidance Report No. 13, Cancer Risk Coefficients for Environmental Exposure to Radionuclides (EPA, 1999).

Values in red exceed the $10^{-4}$ upper bound of the NCP target risk range (CFR, 2009c).

develop the SDWA standards, including the premise that the groundwater will serve as a source for a municipal water supply.

Based on the previous discussion regarding the drinking water standards for radionuclides, it is clear that using an MCL-based approach for establishing contaminant boundaries could result in theoretical risks beyond the contaminant boundary at levels above the upper bound of the acceptable risk range. This situation could be avoided if the contaminant boundary is risk based and accounts for all constituents that are likely to be present.

Conversely, application of both SDWA standards and a risk-based residential use scenario still does not take into account site-specific uses and exposure pathways to groundwater; both assume that drinking water exposures will occur. For CAUs or portions of CAUs contained within the boundaries of the NTS, it is assumed that perpetual controls will exist as the mission of the U.S. Department of Energy, National Nuclear Security Administration Nevada Site Office (NNSA/NSO) is performed. However, the IHI discussion in Section 3.1 indicates that even if no controls were in place, the likelihood of offsite intrusion into areas of contaminated groundwater is very low under the most reasonable future use scenarios. If groundwater is not being consumed at all, there would be zero risk, regardless of contaminant levels; meeting the SDWA would be no more protective than having much higher levels (Daniels and Tompson, 2003). 


\subsection{RISK ChARACtERIZATION}

The protectiveness of the SDWA standards relates, in part, to the definition of the critical group. Title 10 of the Code of Federal Regulations, Part 20, Section 1003, defines the critical group as "the group of individuals reasonably expected to receive the greatest exposure to residual radioactivity for any applicable set of circumstances" (CFR, 2009a). The critical group is often considered synonymous with the Reasonably Maximally Exposed Individual (RMEI). ${ }^{1}$ These definitions form the basis for the underlying conceptual model used to yield bounding (or worst-case) risk estimates.

The risk panel suggested that an alternative approach to using the SDWA radiological standards was to calculate potential doses to the public from contaminated groundwater based on scenarios of future land access. This approach derives a bounding assessment of hypothetical future risks and verifies whether the SDWA standards are protective for all potential land uses, irrespective of the likelihood of exposure or whether a pathway is complete.

This paper is preceded by two risk assessments: the initial evaluation of tritium (IT, 1996), and a more recent probabilistic assessment conducted for the Area 5 performance assessment (DOE/NNSA, 2006b). The latter evaluation was extensive; however, the underlying conceptual model was applied to buried waste. In comparison with the two preceding risk assessments, the risk analysis documented in this report is a quantitatively less rigorous, screening-level evaluation. Simplified (deterministic) assumptions were used as input to risk modeling of extremely complex pathways. Probabilistic risk (entailing the definition of distributions of input parameters) and sensitivity analyses were not conducted. Therefore, it is important to understand that there are uncertainties and caveats associated with the estimates and that the results are intended to elucidate general, rather than definitive, trends or potential outcomes.

1. The National Research Council (NRC, 1995) discusses the concept of a critical group for the Yucca Mountain standards, and Moeller et al. (2007) provide a useful discussion of contrasts between the RMEI and critical group concepts as they relate to the previously proposed Yucca Mountain repository (DOE withdrew the license application in February 2010). 


\subsection{Conceptual Site Model and Analytical Approach}

The conceptual model assumed a resident farmer scenario, analogous to the "homesteader" or "subsistence farmer" scenario used in the previous literature (e.g., Black et al., 2001; NRC, 1995). This scenario assumes individuals live in areas where contaminants are predicted to potentially migrate off the NTS, drill a well, use water from the well for drinking water use and agricultural irrigation (Section 3.1), and produce a substantial fraction of their own food, including vegetables, fruits, grain, meat, and milk.

Using the time-maximum concentrations derived from the transport model for ${ }^{14} \mathrm{C},{ }^{36} \mathrm{Cl},{ }^{3} \mathrm{H},{ }^{129} \mathrm{I}$, and

${ }^{99} \mathrm{Tc}$, corresponding risks were calculated for the exposure pathways identified in Table 5-1, using the input values defined in Tables 5-2 and 5-3. As shown in Tables 5-2 and 5-3-which document general and contaminant-specific exposure assumptions, respectively - with few exceptions, the standard default assumptions in RESRAD Version 6.5 were used. ${ }^{2}$ The RESRAD code has undergone extensive verification and validation and has been used by DOE, EPA, and other federal agencies, and by academia to estimate potential risks from radiological contaminants (ANL, 2001).

Table 5-1

Summary of Pathways Considered for Resident Farmer Scenario (Page 1 of 2)

\begin{tabular}{||l|c|l||}
\hline \multicolumn{1}{|c|}{ Exposure Pathway } & $\begin{array}{c}\text { Pathway } \\
\text { Evaluated? }\end{array}$ & \multicolumn{1}{|c||}{ Comment/Rationale for Selection or Exclusion } \\
\hline \hline Ingestion of groundwater from local well & Yes & $\begin{array}{l}\text { This scenario assumes the use of contaminated } \\
\text { groundwater for consumption. }\end{array}$ \\
\hline Ingestion of food from crops & Yes & $\begin{array}{l}\text { Contaminated groundwater is assumed to be used to } \\
\text { irrigate crops. }\end{array}$ \\
\hline $\begin{array}{l}\text { Ingestion of milk from livestock raised in } \\
\text { the area }\end{array}$ & Yes & $\begin{array}{l}\text { Contaminated groundwater is assumed to be the primary } \\
\text { water source for dairy cows. }\end{array}$ \\
\hline $\begin{array}{l}\text { Ingestion of meat from livestock raised by } \\
\text { the homesteader }\end{array}$ & Yes & $\begin{array}{l}\text { Beef cattle are assumed to have contaminated } \\
\text { groundwater as their primary water source. }\end{array}$ \\
\hline Secondary exposure routes & No & $\begin{array}{l}\text { Other secondary exposure routes (dermal exposure, } \\
\text { inhalation of contaminants in water vapor, direct radiation, } \\
\text { inadvertent soil ingestion and soil inhalation) were not } \\
\text { considered because of their very minor contributions to the } \\
\text { total potential risks. }\end{array}$ \\
\hline
\end{tabular}

2. RESRAD (RESidual RADioactivity) Version 6.5 computer code (released October 30, 2009) can be downloaded from the Argonne National Laboratory website, http://web.ead.anl.gov/resrad/home2/. 


\section{Table 5-1 \\ Summary of Pathways Considered for Resident Farmer Scenario (Page 2 of 2)}

\begin{tabular}{||l|c|l||}
\hline \multicolumn{1}{|c|}{ Exposure Pathway } & $\begin{array}{c}\text { Pathway } \\
\text { Evaluated? }\end{array}$ & Comment/Rationale for Selection or Exclusion \\
\hline $\begin{array}{l}\text { Inhalation of }{ }^{3} \mathrm{H} \text { from evaporation of } \\
\text { groundwater during home use }\end{array}$ & No & $\begin{array}{l}\text { This pathway was found to be negligible compared to other } \\
\text { pathways (IT, 1996). }\end{array}$ \\
\hline $\begin{array}{l}\text { Ingestion of fish from a nearby pond } \\
\text { contaminated by water percolating } \\
\text { through the contaminated zone }\end{array}$ & No & $\begin{array}{l}\text { With the desert environment, lack of any existing surface } \\
\text { water features, and inability to extract a sufficient volume of } \\
\text { contaminated groundwater to establish a viable pond for } \\
\text { fish, this exposure pathway was not evaluated. }\end{array}$ \\
\hline
\end{tabular}

Table 5-2

Summary of Assumed Values Used in Resident Farmer Risk Calculations (Page 1 of 3 )

\begin{tabular}{|c|c|c|c|}
\hline Variable ${ }^{a}$ & Unit & $\begin{array}{l}\text { Assumed } \\
\text { Value }^{b}\end{array}$ & Comments \\
\hline \multicolumn{4}{|c|}{ Exposure Frequency, Exposure Duration, and Human Intake Rates } \\
\hline Exposure frequency & days/year & N/A & $\begin{array}{l}\text { Exposure frequency inherent in pathway-specific } \\
\text { intake rates (e.g., groundwater ingestion) }\end{array}$ \\
\hline Exposure duration & years & 30 & Standard default for residential risk evaluations \\
\hline Water ingestion & L/year & 730 & $\begin{array}{l}\text { Varied from RESRAD default is } 510 \text { L/year ( } 1.4 \text { L/day); } \\
\text { this analysis used } 730 \text { L/year, assuming } 2 \text { L/day for } \\
365 \text { days/year. }\end{array}$ \\
\hline $\begin{array}{l}\text { Fruit, vegetable, and grain } \\
\text { consumption }\end{array}$ & $\mathrm{kg} /$ year & 160 & $\begin{array}{l}\text { RESRAD default; assumes } 50 \% \text { of produce from } \\
\text { affected area }\end{array}$ \\
\hline $\begin{array}{l}\text { Ingestion rate of } \\
\text { leafy vegetables }\end{array}$ & $\mathrm{kg} / \mathrm{year}$ & 14 & $\begin{array}{l}\text { RESRAD default; assumes } 50 \% \text { of produce from } \\
\text { affected area }\end{array}$ \\
\hline Beef ingestion rate & $\mathrm{kg} / \mathrm{year}$ & 63 & $\begin{array}{l}\text { RESRAD default; assumes } 100 \% \text { of meat obtained from } \\
\text { affected area }\end{array}$ \\
\hline Milk ingestion rate & L/year & 92 & $\begin{array}{l}\text { RESRAD default; assumes } 100 \% \text { of milk consumed from } \\
\text { affected area }\end{array}$ \\
\hline \multicolumn{4}{|c|}{ Contamination Fractions of Media/Intake Fractions } \\
\hline $\begin{array}{l}\text { Contamination fractions of } \\
\text { drinking water, livestock water, } \\
\text { and irrigation water }\end{array}$ & unitless & 1.0 & $\begin{array}{l}\text { All domestic (e.g., drinking) water, livestock drinking water, } \\
\text { and irrigation water obtained from well(s) with } \\
\text { contaminants present at levels listed in Table 3-1. }\end{array}$ \\
\hline Contamination fraction, plants & unitless & 0.5 & $\begin{array}{l}\text { RESRAD default; assumes } 50 \% \text { of plant food is not } \\
\text { home grown. }\end{array}$ \\
\hline Contamination fraction of meat & unitless & 1.0 & RESRAD default \\
\hline Contamination fraction of milk & unitless & 1.0 & RESRAD default \\
\hline
\end{tabular}


Table 5-2

Summary of Assumed Values Used in Resident Farmer Risk Calculations (Page 2 of 3)

\begin{tabular}{|c|c|c|c|}
\hline Variable $^{a}$ & Unit & $\begin{array}{l}\text { Assumed } \\
\text { Value }{ }^{b}\end{array}$ & Comments \\
\hline \multicolumn{4}{|c|}{ Irrigation, Climate Parameters } \\
\hline Irrigation applied per year & m/year & 1.0 & $\begin{array}{l}\text { Varied from RESRAD default of } 0.2 \mathrm{~m} / \mathrm{year} \text { (derived for } \\
\text { humid regions with a limited growing season) to account } \\
\text { for the arid climate of the NTS region (ANL, 2001). }\end{array}$ \\
\hline Irrigation mode & $\mathrm{N} / \mathrm{A}$ & $\begin{array}{l}\text { Overhead/ } \\
\text { Ditch }\end{array}$ & $\begin{array}{l}\text { RESRAD was used assuming both modes of irrigation, } \\
\text { although this would likely not be the case; no differences in } \\
\text { fractional dose or risk contributions were apparent in } \\
\text { the output. }\end{array}$ \\
\hline Humidity in air & $\mathrm{g} / \mathrm{m}^{3}$ & 4.7 & $\begin{array}{l}\text { Varied from RESRAD default of } 8 \mathrm{~g} / \mathrm{m}^{3} \text { given the arid } \\
\text { climate of the NTS region; value based on Appendix L, } \\
\text { Figure L-1, in ANL, 2001. }\end{array}$ \\
\hline Evapotranspiration coefficient & unitless & 0.5 & $\begin{array}{l}\text { The RESRAD default was used. Note, however, that this } \\
\text { factor would vary based on precipitation (the more arid } \\
\text { climate of NTS) and other variables. }\end{array}$ \\
\hline Runoff coefficient & unitless & 0.2 & $\begin{array}{l}\text { The RESRAD default was used; however, this factor would } \\
\text { vary based on the terrain (hilly vs. flat), the extent of } \\
\text { vegetative cover, and soil properties/characteristics } \\
\text { (e.g., sand and clay content). }\end{array}$ \\
\hline Precipitation & m/year & 0.1 & $\begin{array}{l}\text { Varied from RESRAD default of } 1 \mathrm{~m} / \mathrm{year} \text { (characteristic of } \\
\text { more temperate regions); annual average cited for lower } \\
\text { elevations of Frenchman Flat CAU (SNJV, 2006, } \\
\text { Section 1.4). }\end{array}$ \\
\hline \multicolumn{4}{|c|}{ Livestock Intake Rates } \\
\hline $\begin{array}{l}\text { Livestock water intake } \\
\text { for meat }\end{array}$ & L/day & 50 & RESRAD default \\
\hline Livestock water intake for milk & L/day & 160 & RESRAD default \\
\hline $\begin{array}{l}\text { Livestock fodder intake } \\
\text { for meat }\end{array}$ & kg/day & 68 & RESRAD default \\
\hline Livestock fodder intake for milk & g/day & 55 & RESRAD default \\
\hline \multicolumn{4}{|c|}{ Plant and Crop Assumptions } \\
\hline $\begin{array}{l}\text { Wet weight crop yield for } \\
\text { non-leafy vegetables }\end{array}$ & $\mathrm{kg} / \mathrm{m}^{2}$ & 0.7 & RESRAD default \\
\hline $\begin{array}{l}\text { Wet weight crop yield for } \\
\text { leafy vegetables }\end{array}$ & $\mathrm{kg} / \mathrm{m}^{2}$ & 1.5 & RESRAD default \\
\hline $\begin{array}{l}\text { Wet weight crop yield } \\
\text { for fodder }\end{array}$ & $\mathrm{kg} / \mathrm{m}^{2}$ & 1.1 & RESRAD default \\
\hline $\begin{array}{l}\text { Growing season for leafy } \\
\text { vegetables }\end{array}$ & years & 0.25 & $\begin{array}{l}\text { RESRAD default, although this could be longer given the } \\
\text { more arid climate. Given the conservatism of other } \\
\text { parameters, the default was retained. }\end{array}$ \\
\hline
\end{tabular}


Table 5-2

Summary of Assumed Values Used in Resident Farmer Risk Calculations (Page 3 of 3)

\begin{tabular}{||l|c|c|l||}
\hline \multicolumn{1}{|c|}{ Variable ${ }^{\text {a }}$} & Unit & $\begin{array}{c}\text { Assumed } \\
\text { Value }\end{array}$ & \multicolumn{1}{|c|}{ Comments } \\
\hline \hline $\begin{array}{l}\text { Growing season for non-leafy } \\
\text { vegetables }\end{array}$ & years & 0.17 & RESRAD default; see comment above. \\
\hline Growing season for fodder & years & 0.08 & RESRAD default \\
\hline Depth of roots & $\mathrm{m}$ & 0.9 & RESRAD default \\
\hline $\begin{array}{l}\text { Translocation factor for } \\
\text { non-leafy vegetables }\end{array}$ & unitless & 0.1 & RESRAD default \\
\hline $\begin{array}{l}\text { Translocation factor for leafy } \\
\text { vegetables and fodder }\end{array}$ & unitless & 1.0 & RESRAD default \\
\hline $\begin{array}{l}\text { Foliar interception fractions } \\
\text { (wet and dry) }\end{array}$ & unitless & 0.25 & $\begin{array}{l}\text { RESRAD default; fraction of deposited activity intercepted } \\
\text { and retained by edible portion of crop. Applies to all } \\
\text { vegetables (leafy, non-leafy) and fodder. }\end{array}$ \\
\hline Weathering removal constant & unitless & 20 & RESRAD default (for vegetation) \\
\hline \hline & \multicolumn{2}{|c|}{ Storage Times } \\
\hline \hline $\begin{array}{l}\text { Fruits, non-leafy vegetables, } \\
\text { and grain }\end{array}$ & days & 14.0 & RESRAD default \\
\hline Leafy vegetables & days & 1.0 & RESRAD default \\
\hline Milk & days & 1.0 & RESRAD default \\
\hline Meat and poultry & days & 20.0 & RESRAD default \\
\hline Well water & days & 1.0 & RESRAD default \\
\hline Livestock fodder & 45.0 & RESRAD default \\
\hline \hline
\end{tabular}

a The table cites the primary variables influencing the risk pathways modeled. RESRAD uses many other parameters and inputs that are secondary and therefore are not listed (ANL, 2001).

${ }^{b}$ Unless otherwise noted, all values taken from RESRAD default (ANL, 2001).

Highlighted variables indicate that the RESRAD default values were not used.

$g=$ Gram

$\mathrm{g} / \mathrm{m}^{3}=$ Grams per cubic meter

$\mathrm{kg}=$ Kilogram

$\mathrm{m}=$ Meter

The RESRAD models and input parameters are realistic but reasonably conservative. ${ }^{3}$ The calculated doses (and, by extension, risks), therefore, are also expected to be reasonably conservative estimates.

3. Although the term "conservative" is widely used in the risk assessment community, it needs to be used and interpreted with caution, as it sometimes implies knowledge about an outcome, probability, or value for which verifying (or validating) data are not always available, e.g., the food chain (plant uptake) parameters listed in Table 5-3. 
Table 5-3

Contaminant-Specific Assumptions Used in the Risk Calculations

\begin{tabular}{||l|c|c|c|c|c||}
\hline \multicolumn{1}{|c|}{ Parameter } & ${ }^{14} \mathbf{C}$ & ${ }^{36} \mathrm{Cl}$ & ${ }^{3} \mathrm{H}$ & ${ }^{129}$ & ${ }^{99} \mathrm{Tc}$ \\
\hline \hline Water ingestion slope factor (risk/pCi) & $1.55 \mathrm{E}-12$ & $3.30 \mathrm{E}-12$ & $1.12 \mathrm{E}-13$ & $1.48 \mathrm{E}-10$ & $2.75 \mathrm{E}-12$ \\
\hline Food ingestion slope factor (risk/pCi) & $2.00 \mathrm{E}-12$ & $4.40 \mathrm{E}-12$ & $1.44 \mathrm{E}-13$ & $3.22 \mathrm{E}-10$ & $4.00 \mathrm{E}-12$ \\
\hline Distribution coefficient (cm $3 / \mathrm{g})$ & 0 & 0.1 & 0 & 0.1 & 0 \\
\hline Plant/soil concentration ratio & 5.5 & 20.0 & 4.8 & 0.02 & 5.0 \\
\hline Beef/livestock-intake ratio (pCi/kg)/(pCi/day) & 0.031 & 0.06 & 0.012 & 0.007 & 0.0001 \\
\hline Milk/livestock-intake ratio (pCi/L)/(pCi/day) & 0.012 & 0.02 & 0.01 & 0.01 & 0.001 \\
\hline Half-life (years) & $5.73 \mathrm{E}+03$ & $3.01 \mathrm{E}+05$ & $1.24 \mathrm{E}+01$ & $1.57 \mathrm{E}+07$ & $2.13 \mathrm{E}+05$ \\
\hline
\end{tabular}

Source: RESRAD default values in ANL (2001)

$\mathrm{cm}^{3} / \mathrm{g}=$ Cubic centimeters per gram

Radionuclide transport through food (resident farmer) pathways is determined by the quantities of different foods consumed (dietary factors); the fraction of the diet from foods that are grown or raised locally and are contaminated; the various transfer factors from root or foliage to plants and from fodder or water to meat or milk; and the predicted contaminant concentrations in groundwater (i.e., irrigation and drinking water).

Resident farmer risk calculations were initiated manually using equations documented in standard source documents (e.g., Baes et al., 1984; NCRP, 1996; IAEA, 2001). RESRAD Version 6.5, however, was used to bracket forecasted groundwater concentrations for water-dependent pathways because of the complex nature of food chain pathways, the uncertainties surrounding uptake factors, and the special treatment required for ${ }^{14} \mathrm{C}$ and ${ }^{3} \mathrm{H} .{ }^{4}$ Fractional dose/risk contributions were then determined for water-dependent pathways.

This approach may result in considerable uncertainty, given the paucity of data regarding food chain uptake values in the literature and reliance on algorithms in commercial codes (which are at times not clearly defined). Furthermore, many of the available risk assessment models were developed assuming a soil (as opposed to groundwater) contaminant source (e.g., ANL, 2001; NCRP, 1996; IAEA, 2001). Therefore, use of default input values will yield preliminary screening-level risk estimates.

4. For ${ }^{14} \mathrm{C}$ and ${ }^{3} \mathrm{H}$, the specific activity approach used in the previous literature (e.g., ANL, 2001; NCRP, 1996; Moeller et al., 2006; Murphy, 1993) was used. 


\section{$5.2 \quad$ Results}

Table 5-4 documents the results of the risk calculations for the PIN STRIPE, MINUTE STEAK, and MILK SHAKE tests, based on the forecasted contaminant boundaries and associated concentrations yielded by the flow and transport model for 1,000 years (NNES, 2010). For comparison, risks corresponding to SDWA standards are also provided (partially duplicating risk-based estimates shown in Table 4-1).

Two sets of risk calculations are provided. First, risks corresponding to drinking water exposures only are presented in columns 6 through 9 of Table 5-4; these estimates correspond to the assumptions in Table 4-1 for a hypothetical 30-year exposure duration. The last four columns in Table 5-4 list the risk estimates derived for the resident farmer scenario using RESRAD default assumptions. Table 5-5 summarizes the four pathway-specific contributions evaluated in the resident farmer scenario: ingestion of drinking water, plants, meat, and milk.

Figures 5-1 and 5-2 show forecasted concentrations and corresponding drinking water risks for each of the three plumes. Figure 5-3 is an annotated adaptation of the offsite plume map shown in Figure 3-5, summarizing the conclusions drawn for each of the three plume areas. The following conclusions were drawn based on the results:

- For drinking water exposure risks, exceedances of a $10^{-4}$ excess cancer risk are yielded only for MINUTE STEAK $\left({ }^{14} \mathrm{C}\right.$ and ${ }^{3} \mathrm{H}$ risks are $2 \times 10^{-4}$ and $1 \times 10^{-3}$, respectively). As shown in Figures 3-5 and 5-3, this plume barely extends beyond the NTS boundary.

- As expected, risks estimated for the resident farmer scenario are higher than those derived for drinking water exposures alone. Fractional risk contributions varied as reflected in Table 5-5, although when interpreting these results, one must acknowledge the uncertainties inherent in these pathway evaluations.

- For the resident farmer scenario, all contaminants except for ${ }^{129} \mathrm{I}$ and ${ }^{99} \mathrm{Tc}$ would result in risks exceeding $10^{-4}$ for both MINUTE STEAK and MILK SHAKE plumes. Risks corresponding to SDWA standards would also exceed $10^{-4}$ for ${ }^{14} \mathrm{C},{ }^{36} \mathrm{Cl}$, and ${ }^{99} \mathrm{Tc}$ for the resident farmer scenario.

- The MINUTE STEAK plume, which barely extends past the NTS boundary, would result in the greatest risks, if the pathways are complete. 
Table 5-4

Results of Risk Calculations for PIN STRIPE, MINUTE STEAK, and MILK SHAKE Contaminant Boundaries

\begin{tabular}{|c|c|c|c|c|c|c|c|c|c|c|c|c|}
\hline \multirow[b]{2}{*}{$\begin{array}{l}\frac{0}{0} \\
\frac{.}{0} \\
\frac{0}{2} \\
\frac{0}{0} \\
\frac{0}{0} \\
\text { ㄸ }\end{array}$} & \multirow[b]{2}{*}{ 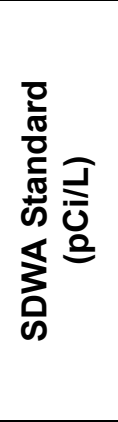 } & \multicolumn{3}{|c|}{$\begin{array}{c}\text { Forecasted Groundwater } \\
\text { Concentrations }\end{array}$} & \multicolumn{4}{|c|}{ Drinking Water Exposure Risks Only } & \multicolumn{4}{|c|}{$\begin{array}{c}\text { Homesteader/Resident Farmer } \\
\text { Scenario Risks }\end{array}$} \\
\hline & & 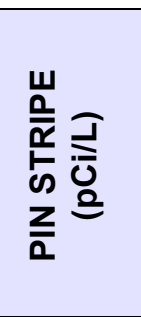 & 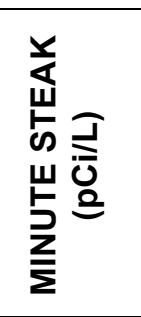 & 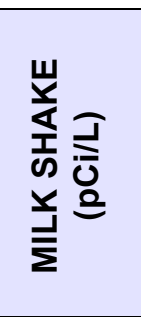 & 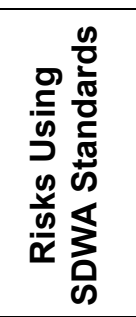 & 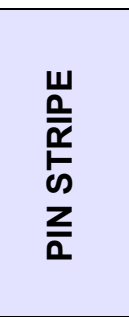 & 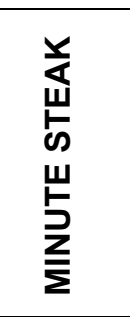 & 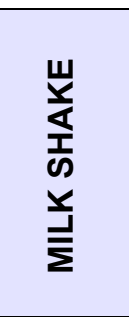 & 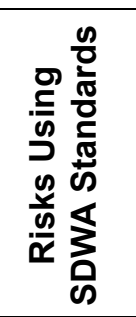 & $\begin{array}{l}w \\
\frac{\alpha}{\alpha} \\
\text { 心 } \\
\frac{Z}{a}\end{array}$ & 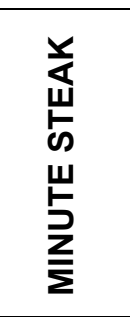 & 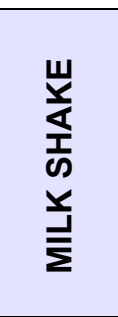 \\
\hline${ }^{14} \mathrm{C}$ & 2,000 & $5.1 \mathrm{E}+02$ & $6.5 \mathrm{E}+03$ & $1.0 \mathrm{E}+03$ & $6.8 \mathrm{E}-05$ & 1.7E-05 & $2.2 \mathrm{E}-04$ & $3.4 \mathrm{E}-05$ & $3.1 \mathrm{E}-04$ & $7.8 \mathrm{E}-05$ & 9.9E-04 & $1.5 \mathrm{E}-04$ \\
\hline${ }^{36} \mathrm{Cl}$ & 700 & $4.4 \mathrm{E}+01$ & $5.4 \mathrm{E}+02$ & $1.1 \mathrm{E}+02$ & $5.1 \mathrm{E}-05$ & $3.2 \mathrm{E}-06$ & 3.9E-05 & $7.9 \mathrm{E}-06$ & 7.3E-04 & 4.6E-05 & 5.7E-04 & 1.2E-04 \\
\hline${ }^{3} \mathrm{H}$ & 20,000 & $1.2 \mathrm{E}+03$ & $5.2 \mathrm{E}+05$ & $5.0 \mathrm{E}+01$ & 4.9E-05 & 2.9E-06 & 1.3E-03 & 1.2E-07 & 8.3E-05 & 5.0E-06 & $2.2 \mathrm{E}-03$ & 2.1E-07 \\
\hline $129 \mid$ & 1 & $2.8 \mathrm{E}-02$ & $3.1 \mathrm{E}-01$ & 7.3E-02 & $3.2 \mathrm{E}-06$ & $9.1 \mathrm{E}-08$ & 1.0E-06 & $2.4 \mathrm{E}-07$ & 1.5E-05 & $4.1 \mathrm{E}-07$ & $4.5 \mathrm{E}-06$ & 1.1E-06 \\
\hline${ }^{99} \mathrm{TC}$ & 900 & $2.9 \mathrm{E}+00$ & $3.9 \mathrm{E}+01$ & $7.5 \mathrm{E}+00$ & $5.4 \mathrm{E}-05$ & 1.7E-07 & 2.3E-06 & 4.5E-07 & 1.1E-04 & $3.5 \mathrm{E}-07$ & 4.7E-06 & 9.0E-07 \\
\hline
\end{tabular}

Notes:

Risks were calculated using exposure parameters and models in RESRAD Version 6.5. Numerous iterations were conducted using the exposure parameters documented in

Tables 5-2 and 5-3 to bracket forecasted contaminant concentrations. Fractional dose/risk contributions were then determined for water-dependent pathways. Highlighted

groundwater concentrations exceed corresponding SDWA standards; risk estimates in red exceed 10-4 (upper bound of NCP target risk range [CFR, 2009c]). The estimated risks associated with the homesteader/resident farmer scenario include contributions from the following pathways: ingestion of groundwater, plant tissue, meat, and milk (see Table 5-5). 
Table 5-5

Summary of Pathway-Specific Contributions

\begin{tabular}{|c|c|c|c|c|c|}
\hline Radionuclide & $\begin{array}{l}\text { Drinking } \\
\text { Water } \\
(\%)\end{array}$ & $\begin{array}{c}\text { Plant } \\
\text { (\%) }\end{array}$ & $\begin{array}{c}\text { Meat } \\
(\%)\end{array}$ & $\begin{array}{c}\text { Milk } \\
(\%)\end{array}$ & Comment \\
\hline${ }^{14} \mathrm{C}$ & 22 & $46^{a}$ & 20 & 11 & $\begin{array}{l}\text { The plant pathway dominates the estimated risks } \\
\text { because edible plants and agricultural crops contain the } \\
\text { majority }(>90 \% \text { ) of available carbon (NCRP, 1996; } \\
\text { Moeller et al., 2006). Although these results are not } \\
\text { directly comparable to fractional dose (vs. risk) } \\
\text { contributions, they are somewhat consistent with dose } \\
\text { estimates cited by Moeller et al. (2007) for an Amargosa } \\
\text { Valley case study. In that study, relative percent } \\
\text { contributions to total doses from groundwater ingestion } \\
\text { and locally produced agricultural crops and animal } \\
\text { products for }{ }^{14} \mathrm{C} \text { were about } 30 \% \text { and } 70 \% \text {, respectively. }\end{array}$ \\
\hline${ }^{36} \mathrm{Cl}$ & 7 & 15 & $54^{a}$ & 24 & $\begin{array}{l}\text { The relative unimportance of the drinking water pathway } \\
\text { for this parameter reflects default RESRAD assumptions } \\
\text { and may result in an overly conservative estimate of } \\
\text { total resident farmer risks. }\end{array}$ \\
\hline${ }^{3} \mathrm{H}$ & $58^{a}$ & 26 & 6 & 10 & $\begin{array}{l}\text { The results from this evaluation are generally consistent } \\
\text { with those documented in an earlier (Phase I) risk } \\
\text { assessment for UGTA (IT, 1996), in which the drinking } \\
\text { water and food ingestion exposure pathways contributed } \\
\text { approximately } 54 \% \text { and } 45 \% \text {, respectively, of the total } \\
\text { risk from }{ }^{3} \mathrm{H} \text {. }{ }^{\mathrm{b}}\end{array}$ \\
\hline 129 & 22 & 13 & 22 & $43^{a}$ & $\begin{array}{l}\text { Similar to the comment above for }{ }^{36} \mathrm{Cl} \text {, the dominance of } \\
\text { the milk pathway for this parameter reflects use of } \\
\text { RESRAD default assumptions and should be revisited if } \\
\text { further risk analysis is warranted for the NTS in the } \\
\text { future. Moeller et al. (2007) cite fractional dose } \\
\text { contributions of } 64 \% \text { and } 46 \% \text { for drinking water and } \\
\text { food intakes, respectively. (Again, acknowledge } \\
\text { distinction between doses and risks). }\end{array}$ \\
\hline${ }^{99} \mathrm{Tc}$ & $49^{a}$ & 43 & $<1$ & 7 & $\begin{array}{l}\text { Fractional risk contributions are similar to dose } \\
\text { contributions cited by Moeller et al. ( } 2007) \text {, about } 50 \% \\
\text { for both drinking water and total food intakes. }\end{array}$ \\
\hline
\end{tabular}

a Pathway dominates total homesteader/resident farmer risk. Due to rounding, the sums of the contributions from the intake of water and food do not always total $100 \%$.

${ }^{b}$ Note that soil moisture (which could influence ${ }^{3} \mathrm{H}$ transport in the food chain) is not a RESRAD input parameter and is determined based on other parameters (ANL, 2001).

- None of the estimated risks associated with the PIN STRIPE plume exceeds $10^{-4}$.

- Considerable variability exists among the pathway-specific contributions by contaminant. The pathway contribution is likely dictated by properties of the various contaminants to bioconcentrate in different media, and inherent uncertainties are not adequately accounted for given the scope of this evaluation. 


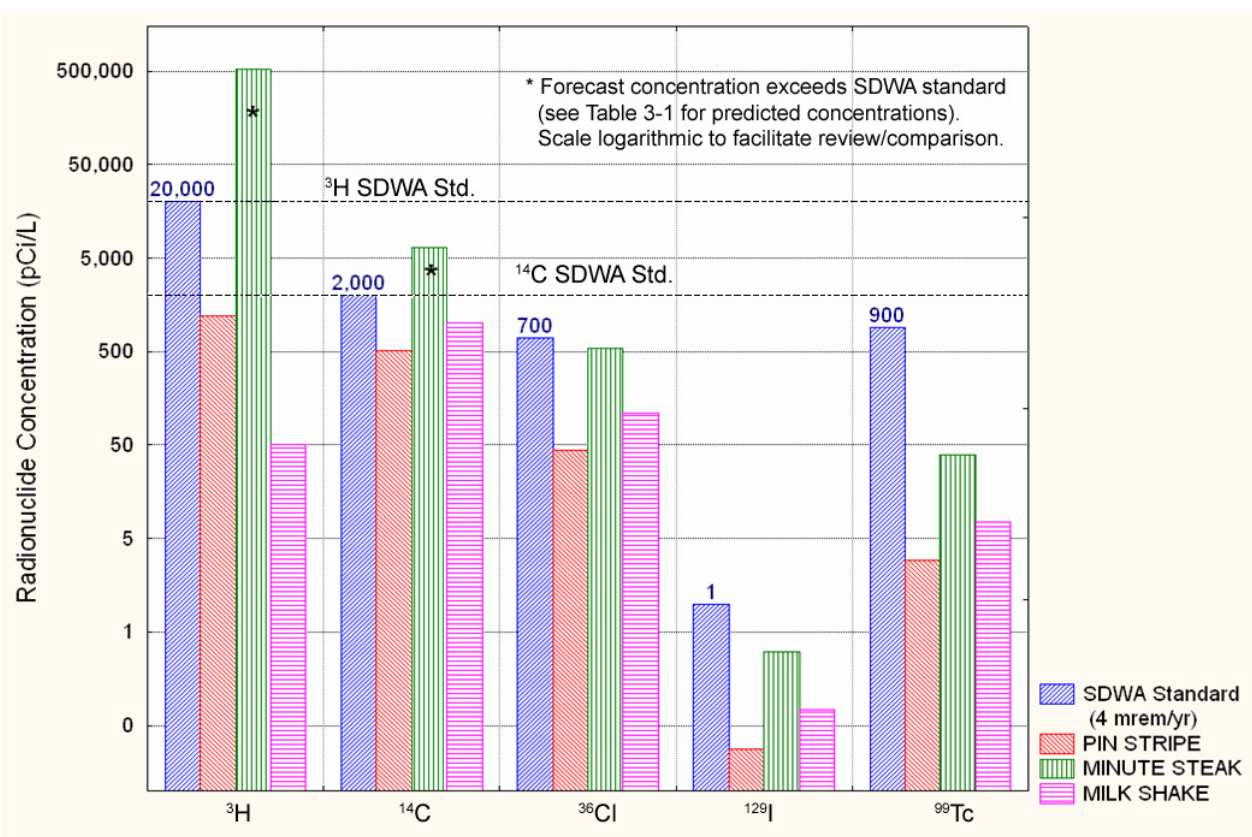

Figure 5-1

Forecasted Radionuclide Concentrations Relative to SDWA Standards

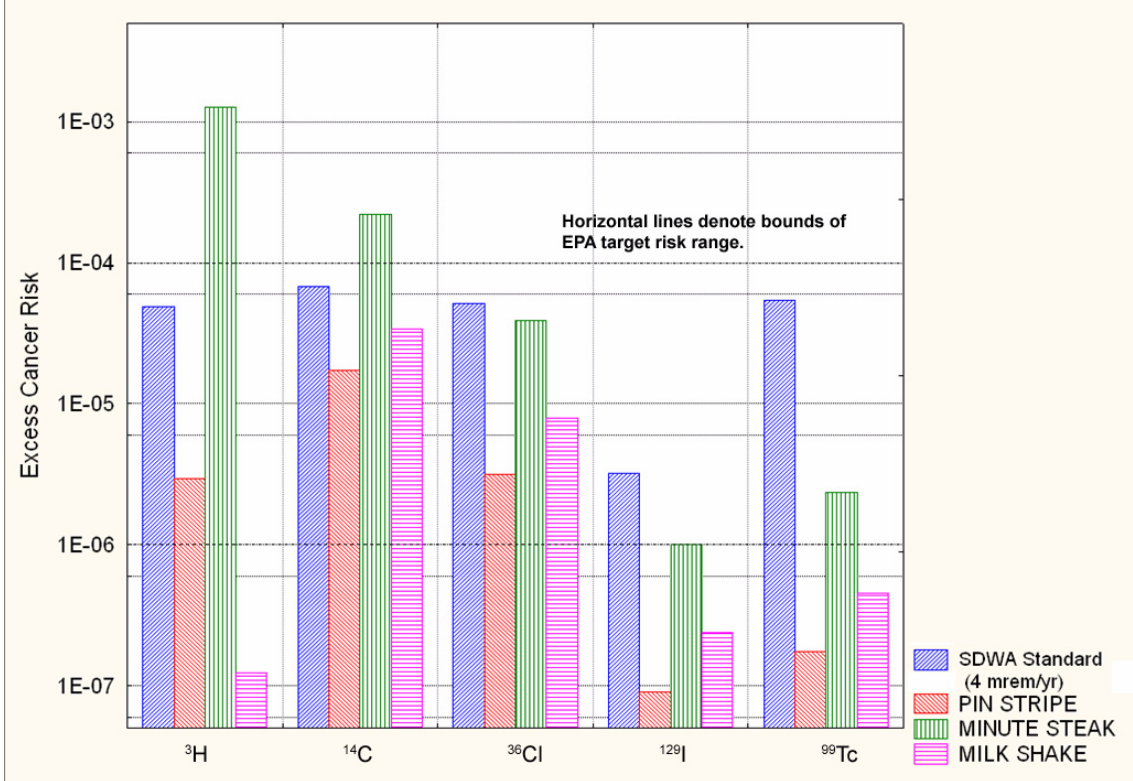

Figure 5-2

Drinking Water Risks for Forecasted Radionuclide Concentrations 


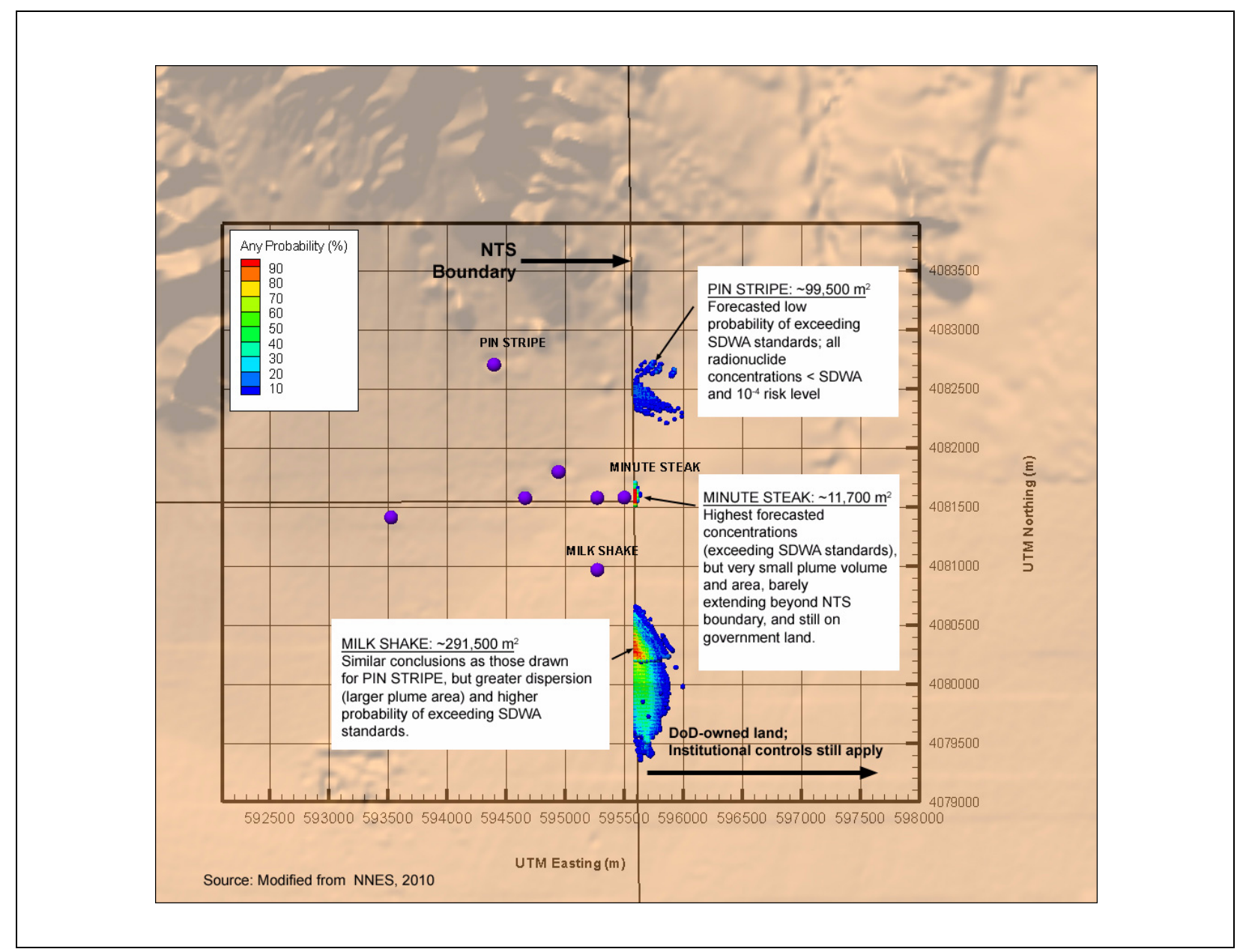

Figure 5-3

Summary of Fate and Transport Modeling Results Combined with Risk Results

The results assume that the resident farmer exposure pathways are complete, although this is extremely unlikely because of the depth to groundwater, the limited extent of the plumes outside the NTS boundary, the isolation of the site and the location and extent of government land, and the existence of institutional controls. Moreover, if the pathways were complete, the risks are considered to approximate worst-case, or bounding, estimates, due to the generally conservative nature of the exposure assumptions. For example, this analysis assumes that the resident farmer lives on site for 30 years and that contaminated groundwater is used exclusively for drinking and agricultural irrigation purposes.

A probabilistic risk analysis was not conducted because it is beyond the scope of this paper. Given the hypothetical nature of the scenarios, current or projected land uses, and the low probability of 
future occurrence of the postulated scenarios, a more rigorous evaluation was not considered warranted at this time. However, such an analysis would need to expand on the likelihood of food pathways and corresponding fractional contributions to total risks and doses.

Overall, this evaluation demonstrates that, although some contaminant concentrations greater than the SDWA standards may occur outside the NTS boundary, the probabilities of exceeding the standards are generally low, and the plumes barely extend beyond the site boundaries. This results in a low probability for the resident farmer scenario to be a complete exposure pathway.

It is important to reiterate that the risk estimates listed in Table 5-4 are expressions of the probability of contracting cancer beyond the normal incidence rate due to exposure to the radionuclides at the forecasted concentrations. However, these expressions assume that pathways are complete —an assumption needed to account for the critical group/RMEI. Therefore, it is important to evaluate the likelihood of a complete exposure pathway. To make the risk estimates listed in Table 5-4 more realistic, the following section evaluates the probabilities of exposure given projected land uses surrounding the NTS and accounting for plume size.

\subsection{Probabilities for a Complete Exposure Scenario}

The expected risk in Black et al. (2001) was established as the product of the consequences and the probability of IHI into a radioactive waste disposal site. To apply this risk equation to the UGTA contaminated-groundwater problem, the consequences of a member of the public drilling into and using contaminated groundwater were substituted for the consequences of IHI into a radioactive waste disposal site.

The hazard or probability of IHI is defined from Black et al. (2001) as:

$$
p(\mathrm{IHI})=1-(1-r)^{n}
$$

where $p(\mathrm{IHI})$ is redefined as the probability of inadvertently encountering and using contaminated groundwater; $r$ is the footprint of the area of interest divided by the area of Frenchman Flat basin (350 square kilometers $\left[\mathrm{km}^{2}\right]$ ); and $n$ is the number of estimated drill holes in Frenchman Flat in 1,000 years. The $p(\mathrm{IHI})$ is defined in Black et al. (2001) as the probability of inadvertently drilling into a shallow-land-burial disposal site (less than $10 \mathrm{~m}$ in depth); we assume for simplicity of 
calculations that the elicitation results can be applied to drilling to groundwater (150 to $225 \mathrm{~m}$ below ground surface). The footprint area $(r)$ is equated with the area of contaminant plumes outside the NTS boundaries (see footnote a to Table 5-6), and the number of drill holes $(n)$ is established from a deterministic run of the GoldSim model for the Area 5 Radioactive Waste Management Site in Frenchman Flat (see footnote b to Table 5-6), which implements the active and passive institutional control policies of Black et al. (2001) for the Frenchman Flat basin.

The GoldSim model uses the parameters of the influence diagram of the Jackass Flats commuter homesteader scenario, which had the highest IHI probabilities of the four IHI scenarios evaluated. This scenario assumes a random location of borehole sites in the Frenchman Flat basin and a probability distribution for the likelihood of loss of institutional control of the NTS boundaries over 10,000 years. The current NNSA/NSO policy, which was established after completion of the study by Black et al. (2001), requires that institutional controls remain in place in perpetuity. Not using the Jackass Flats scenario would reduce the number of expected drill holes in Frenchman Flat in 1,000 years by more than an order of magnitude. Moreover, retaining institutional control of the NTS in perpetuity would likely reduce the settlement rate for the commuter homesteader scenario in Frenchman Flat, the number of estimated future boreholes, and the $p(\mathrm{IHI})$. Note also that the Jackass Flats scenario assumes a combination of community water supply wells and individual private wells. Community water supply wells would be subject to regulation under the SDWA. These regulations require periodic testing and treatment, if necessary. For exposures to NTS-contaminated groundwater to occur via a community well, the water supply system would be out of compliance. Exposure to contamination would be most likely only through the use of unregulated private wells, and the number of wells used in the Jackass Flats scenario is an overestimation. To summarize, multiple factors used in Equation 5-1 are overestimated, and therefore, the resulting $p(\mathrm{IHI})$ are expected to be bounding.

The purpose of evaluating Equation 5-1 is to determine whether $p(\mathrm{IHI})$ approaches 1 for randomly located groundwater wells in Frenchman Flat over 1,000 years. If this probability is less than 1, the estimated drinking water risks from Figure 5-2 would be reduced. Table 5-6 lists the parameters of Equation 5-1 and $p(\mathrm{IHI})$ for the ten underground tests conducted in Frenchman Flat. The plume areas for the offsite plumes (the PIN STRIPE, MINUTE STEAK, and MILK SHAKE tests) are from Figure 3-4; the plume areas for the composite plumes (within and extending off the NTS) are from 
Table 5-6

Parameters for $p(I H I)$ Calculation for Offsite Groundwater Contamination

\begin{tabular}{|c|c|c|c|c|c|c|c|}
\hline $\begin{array}{l}\text { Underground Test } \\
\text { Frenchman Flat }\end{array}$ & $\begin{array}{c}\text { Total } \\
\text { Plume Area } \\
\left(\mathrm{m}^{2}\right)\end{array}$ & $\begin{array}{l}\text { Intersection } \\
\text { Ratio for } \\
\text { Total } \\
\text { Plume Area }\end{array}$ & $\begin{array}{c}p(\mathrm{IHI}) \\
1,000 \text { years }^{b}\end{array}$ & $\begin{array}{c}\text { Offsite } \\
\text { Plume Area } \\
\left(\mathrm{m}^{2}\right)\end{array}$ & $\begin{array}{l}\text { Intersection } \\
\text { Ratio for } \\
\text { Offsite } \\
\text { Plume Area }\end{array}$ & $\begin{array}{c}p(\mathrm{IHI}) \\
1,000 \text { years }^{b}\end{array}$ & Scenario $^{\mathrm{c}}$ \\
\hline DERRINGER & 15,738 & $4.50 \mathrm{E}-05$ & 0.005 & $\mathrm{~N} / \mathrm{A}$ & $\mathrm{N} / \mathrm{A}$ & $\mathrm{N} / \mathrm{A}$ & BASE-USGSD \\
\hline DIAGONAL LINE & 22,082 & $6.31 \mathrm{E}-05$ & 0.007 & $\mathrm{~N} / \mathrm{A}$ & $\mathrm{N} / \mathrm{A}$ & $\mathrm{N} / \mathrm{A}$ & BASE-USGSD \\
\hline $\begin{array}{l}\text { DIANA MOON/ } \\
\text { MINUTE STEAK }\end{array}$ & 18,385 & $5.25 \mathrm{E}-05$ & 0.006 & 11,688 & 3.3E-05 & 0.004 & BASE-USGSD \\
\hline MILK SHAKE & 510,773 & $1.46 \mathrm{E}-03$ & 0.16 & 291,496 & 8.3E-04 & 0.09 & NHA-USGSD \\
\hline NEW POINT & 15,725 & 4.49E-05 & 0.005 & $\mathrm{~N} / \mathrm{A}$ & $\mathrm{N} / \mathrm{A}$ & $\mathrm{N} / \mathrm{A}$ & BASE-USGSD \\
\hline PIN STRIPE & 323,071 & $9.23 E-04$ & 0.10 & 99,542 & $2.8 \mathrm{E}-04$ & 0.03 & BASE-USGSD; disp \\
\hline $\begin{array}{c}\text { CAMBRIC/ } \\
\text { DILUTED WATERS }\end{array}$ & $1,244,953$ & $3.56 \mathrm{E}-03$ & 0.39 & $\mathrm{~N} / \mathrm{A}$ & $\mathrm{N} / \mathrm{A}$ & $\mathrm{N} / \mathrm{A}$ & BASE-USGSD \\
\hline WISHBONE & 24,356 & 6.96E-05 & 0.01 & $\mathrm{~N} / \mathrm{A}$ & $\mathrm{N} / \mathrm{A}$ & N/A & BASE-USGSD \\
\hline Northern Test Area & 905,774 & $2.59 E-03$ & 0.28 & 402,726 & $1.2 E-03$ & 0.13 & Sum North Test Area \\
\hline Southern Test Area & $1,269,309$ & $3.63 E-03$ & 0.40 & $N / A$ & $N / A$ & $N / A$ & Sum South Test Area \\
\hline All Frenchman Flat Tests & $2,175,083$ & 6.21E-03 & 0.68 & 402,726 & 1.2E-03 & 0.13 & Sum of All Tests \\
\hline
\end{tabular}

a Probability of intersection is represented as the offsite footprint area divided by the area of Frenchman Flat ( $\left.3.5 \mathrm{E}+08 \mathrm{~m}^{2}\right)$. Assuming institutional control in perpetuity, the intersection ratio, $r$, would be represented as the footprint area divided by the offsite area of Frenchman Flat. This requires adjusting the Black et al. (2001) approach to estimating the number of drill holes to correspond to the reduced offsite area of Frenchman Flat. This adjustment cannot be made without changing the assumptions of the Black et al. (2001) study.

Assuming random location of drill holes, the expected reduction in the number of drill holes can be approximated as the ratio of the offsite area of Frenchman Flat divided by the

area of Frenchman Flat. Through substitution, these adjustments in $r$ using the reduced number of drill holes result in about the same value of $p$ (IHI) obtained with the offsite plume area and the area of Frenchman Flat. To preserve the approach and assumptions of the Black et al. (2001) study, $r$ is represented simply as the footprint area divided by the area of Frenchman Flat.

b Probability of $\mathrm{IHI}$ is from Equation 5-1, where $r$ is the intersection ratio and $n$ is the number of drill holes in Frenchman Flat in 1,000 years. The value of $n$ used in this table is 110 .

This number was obtained from a deterministic run of the Area 5 Radioactive Waste Management Site GoldSim model with active and passive institutional controls set to on for the model run.

c The scenario labels are from the model cases used in the Phase II transport model for CAU 98 (NNES, 2010). 
Figure 3-5. The table shows that the intersection ratios for the offsite plume areas are small and that the $p(\mathrm{IHI})$ for these tests are much less than 1. The intersection ratios for the total plume areas both on and off the NTS are also small, and the $p$ (IHI) for all tests range from 0.005 to 0.39 , with the highest value of $p(\mathrm{IHI})$ corresponding to the CAMBRIC test, where pumping and surface release of contaminated groundwater greatly expanded the plume footprint. The $p(\mathrm{IHI})$ for the cumulative plume area of all tests in Frenchman Flat is 0.68.

The probabilities of future drilling into the offsite plumes of Table 5-6 would be multiplied by the drinking water exposure risks of the homesteader/resident farmer scenario risks listed in Table 5-4 for comparison with the SDWA. These calculations would give risks that are, for all cases of the offsite plumes, less than the $10^{-4}$ upper bound of the NCP target risk range from CFR $(2009 \mathrm{c})$. The risk calculations (exposure risk times scenario probability), however, are not completed for two reasons. First, the plume concentrations for the onsite plume areas were not evaluated for this study consistent with current institutional control policies for the NTS (no completed exposure pathway). Second, the $p(\mathrm{IHI})$ numbers in Table 5-6 are bounding estimates using extrapolated data from the IHI study of Black et al. (2001). There is confidence that the probabilities are low, but the numbers are based on bounding assumptions of no institutional control and an exposure scenario that is probably not applicable (Jackass Flats scenario). 


\subsection{CONCLUSIONS}

A necessary prelude to this concluding section is reiteration of the following three critical assumptions and site conditions. First, contaminated groundwater from underground testing of nuclear weapons is deep below the ground surface (150 to $225 \mathrm{~m}$ below the surface in Frenchman Flat), and there are no natural release pathways to the surface (e.g., springs). Thus, doses to the public require access to groundwater, which is only expected to occur from scenarios of future drilling for access to groundwater. Second, land access on the NTS is currently restricted by NNSA through active institutional controls, and these controls are expected to remain in place in perpetuity. Finally, the fate and transport analysis used to forecast contaminant concentrations at and beyond the site boundary tends to overestimate radionuclide release from radiological source term and transport in groundwater.

As discussed in Section 1.0, this report was prepared in response to the risk panel's question whether the SDWA standards are sufficiently protective of public health and safety. As demonstrated in Section 5.0, if pathways other than drinking water are taken into consideration, risks would increase. However, given current and projected future land uses both on and off the NTS (government-owned lands with institutional controls in place), this increase is relatively insignificant, and the SDWA standards are protective. The following conclusions are drawn from the evaluations completed for this report:

- Use of the $95^{\text {th }}$ percentile approach to establish the perimeter of the contaminant boundary results in contaminant concentrations at the contaminant boundary that, with few exceptions, are less than the SDWA standards.

- Assuming a hypothetical critical group scenario consisting of a resident (or subsistence) farmer residing at or near the NTS boundary, use of SDWA standards to establish contaminant boundaries could result in risks exceeding the acceptable risk range (i.e., greater than $10^{-4}$ ) at the contaminant boundary because of the presence of multiple radionuclides and multiple exposure pathways (drinking water, plant, and meat ingestion). 
- For Frenchman Flat, use of SDWA standards as a basis for establishing the contaminant boundary appears to be protective, given current and projected future land uses and an expected low probability of public access to contaminated groundwater.

- Because of institutional controls, location of the site on government-owned land, the relatively small spatial extent of the plumes, isolation of the site, and deep depth of the groundwater beneath the land surface, the likelihood of a complete pathway is low to extremely low, and therefore, any simulated risks from contaminant plumes modeled for the Frenchman Flat CAU are small.

- Fully effective institutional controls over 1,000 years eliminate the potential for any risks at this site. These controls could become less effective or may fail in the future, but they may also remain intact over the next 1,000 years. This report assumed failure of institutional controls to estimate future potential risks; however, this assumption overestimates risk with respect to the SDWA. 


\subsection{REFERENCES}

ANL, see Argonne National Laboratory.

Argonne National Laboratory. 2001. User's Manual for RESRAD Version 6, ANL/EAD-4, prepared by C. Yu, A.J. Zielen, J.-J. Cheng, D.J. LePoire, E. Gnanapragasam, S. Kamboj, J. Arnish, A. Wallo III, W.A. Williams, and H. Peterson for the Argonne National Laboratory Environmental Assessment Division. Argonne, IL.

Baes, C.F., III, R.D. Sharp, A.L. Sjoreen, and R.W. Shor. 1984. A Review and Analysis of Parameters for Assessing Transport of Environmentally Released Radionuclides through Agriculture, ORNL-5786. Oak Ridge, TN: Oak Ridge National Laboratory.

Black, P., K. Black, L. Stahl, M. Hooten, T. Stockton, and D. Neptune. 2001. Assessing the Probability of Inadvertent Human Intrusion at the Nevada Test Site Radioactive Waste Management Sites - Volume I. DOE/NV-593-Vol. I. Prepared for the U.S. Department of Energy Nevada Operations Office under Argonne National Laboratory Contract Number W-31-109-Eng-38.

CFR, see Code of Federal Regulations.

Code of Federal Regulations. 2009a. Title 10 CFR Part 20, "Standards for Protection Against Radiation.” Washington, DC: U.S. Government Printing Office.

Code of Federal Regulations. 2009b. Title 40 CFR Part 141, "National Primary Drinking Water Regulations." Washington, DC: U.S. Government Printing Office.

Code of Federal Regulations. 2009c. Title 40 CFR Part 300, "National Oil and Hazardous Substances Pollution Contingency Plan.” Washington, DC: U.S. Government Printing Office.

Daniels, J.I., and A.F.B. Tompson. 2003. Technical Basis for Also Using Health-Risk Assessment to Establish Contaminant Boundaries for Corrective Action Units (CAUs) of the Underground Test Area (UGTA) at the Nevada Test Site (NTS), UCRL-TR-201702. Livermore, CA: Lawrence Livermore National Laboratory.

DOE, see U.S. Department of Energy.

DOE/NV, see U.S. Department of Energy, Nevada Operations Office. 
EPA, see U.S. Environmental Protection Agency.

FFACO, see Federal Facility Agreement and Consent Order.

Federal Facility Agreement and Consent Order. 1996 (as amended March 2010). Agreed to by the State of Nevada; U.S. Department of Energy, Environmental Management; U.S. Department of Defense; and U.S. Department of Energy, Legacy Management. Appendix VI, which contains the Underground Test Area Strategy, was last amended in June 2009, Revision No. 3.

IAEA, see International Atomic Energy Agency.

IT, see IT Corporation.

International Atomic Energy Agency. 2001. Generic Models for Use in Assessing the Impact of Discharges of Radioactive Substances to the Environment, Safety Reports Series No. 19. Vienna, Austria.

IT Corporation. 1996. Underground Test Area Subproject Phase I Data Analysis Task, Volume VIII: Risk Assessment Documentation Package, ITLV/10972-181. Prepared for the U.S. Department of Energy, Nevada Operations Office. Las Vegas, NV.

Moeller, D.W., M.T. Ryan, R.N. Cherry, and L.C. Sun. 2006. "Significance of ${ }^{14} \mathrm{C}$ and ${ }^{228} \mathrm{Ra}$ in Terms of the Proposed Yucca Mountain High-Level Radioactive Waste Repository." In Health Physics 91 (3): 238-248.

Moeller, D.W., M.T. Ryan, and L.C. Sun. 2007. "Factors Affecting Dose Estimates for Long-Term Performance Assessments: Case Study_Amargosa Valley.” In Health Physics 92 (2): 127-133.

Murphy, C.E., Jr. 1993. "Tritium Transport and Cycling in the Environment." In Health Physics 65 (6): 683-697.

NCRP, see National Council on Radiation Protection and Measurements.

N-I GIS, see Navarro-Intera Geographic Information Systems.

NNES, see Navarro Nevada Environmental Services, LLC.

NNSA/NSO, see U.S. Department of Energy, National Nuclear Security Administration Nevada Site Office.

NRC, see National Research Council.

National Council on Radiation Protection and Measurements. 1996. Screening Models for Releases of Radionuclides to Atmosphere, Surface Water, and Ground, NCRP Report No. 1231. Bethesda, MD. 
National Research Council. 1995. Technical Bases for Yucca Mountain Standards. Washington, DC: National Academy Press.

Navarro-Intera Geographic Information Systems. 2010. ESRI ArcGIS Software.

Navarro Nevada Environmental Services, LLC. 2010. Phase II Transport Model of Corrective Action Unit 98: Frenchman Flat, Nevada Test Site, Nye County, Nevada, Rev. 1, N-I/28091--004, S-N/99205--122. Las Vegas, NV.

SNJV, see Stoller-Navarro Joint Venture.

Stoller-Navarro Joint Venture. 2006. Phase II Groundwater Flow Model of Corrective Action Unit 98: Frenchman Flat, Nye County, Nevada, Rev. 0, S-N/99205--074. Las Vegas, NV.

Stoller-Navarro Joint Venture. 2009. Phase I Transport Model of Corrective Action Units 101 and 102: Central and Western Pahute Mesa, Nevada Test Site, Nye County, Nevada, Rev. 1, S-N/99205--111. Las Vegas, NV.

U.S. Department of Energy. 2001. Radioactive Waste Management. DOE Order 435.1, Change 1. Washington, DC.

U.S. Department of Energy, Nevada Operations Office. 1997. Regional Groundwater Flow and Tritium Transport Modeling and Risk Assessment of the Underground Test Area, Nevada Test Site, Nevada, DOE/NV--477, UC-700. Las Vegas, NV.

U.S. Department of Energy, National Nuclear Security Administration Nevada Site Office. 2006a. Nevada Test Site Environmental Management End State Vision, DOE/NV--958. Las Vegas, NV.

U.S. Department of Energy, National Nuclear Security Administration Nevada Site Office. 2006b. Addendum 2 to the Performance Assessment for the Area 5 Radioactive Waste Management Site at the Nevada Test Site, Nye County, Nevada: Update of Performance Assessment Methods and Results. Prepared by Bechtel Nevada Neptune and Company, Inc. June. Las Vegas, NV.

U.S. Environmental Protection Agency. 1999. Cancer Risk Coefficients for Environmental Exposure to Radionuclides, Federal Guidance Report No. 13, EPA 402-R-99-001. Washington, DC. 
Appendix A

External Risk Review Panel Findings

(23 Pages) 


\title{
FRENCHMAN FLAT CORRECTIVE ACTION UNIT REVIEW OF THE RISK BASIS FOR THE CORRECTIVE ACTION STRATEGY
}

\section{FINAL REPORT}

MAY 8, 2009

\author{
PREPARED BY \\ THE EXTERNAL RISK REVIEW PANEL \\ FOR THE FRENCHMAN FLAT CORRECTIVE ACTION UNIT \\ OF THE UNDERGROUND TESTING AREA \\ AT THE NEVADA TEST SITE
}




\subsection{INTRODUCTION}

This report has been prepared to summarize the technical review conducted by the external risk review panel ("the risk panel") that was convened by the U.S. Department of Energy (DOE) Nevada Site Office (NSO) and its contractor (Stoller-Navarro Joint Venture [SNJV]). Specifically, the team was tasked to answer two questions related to the adequacy of the risk-bases incorporated into the correction action strategy considered for the Frenchman Flat (FF) Corrective Action Unit (CAU) on the Underground Test Area (UGTA) of the Nevada Test Site (NTS). DOE is planning on moving towards the next phase of the closure strategy for the FF-CAU as described in the Federal Facility Agreement and Consent Order (FFACO). This next phase (Corrective Action Decision Document/Corrective Action Plan or CADD/CAP) involves defining a compliance boundary.

A kick-off meeting was held on February 19, 2009 at the DOE-NSO in Las Vegas, NV. At the kick-off meeting, the risk panel was provided a briefing on the status of current activities including the progress of the transport model. DOE-NSO and SNJV managers emphasized to the risk panel that the latest FFACO strategy that would be applicable to all CAUs on the Nevada Test Site, including the FF-CAU, specifies using the SDWA standards as the foundation for a model-derived contaminant boundary. This boundary would then serve as a basis for subsequent discussions and negotiations for a compliance boundary.

The risk panel agreed to continue discussions by phone in order to produce the deliverable (this report), which was requested by DOE-NSO and SNJV. Specific objectives of this review and the approach used by the risk panel to meet these objectives are described in Sections 2.0 and 3.0, respectively. The responses to questions are identified as findings as presented in Section 4.0. Recommendations from panel members are discussed in Section 5.0. References cited in Sections 2.0 to 5.0 are identified in brackets based on the numbering system used in Section 7.0.

The composition of the risk panel is multidisciplinary with backgrounds in groundwater modeling, decision support, uncertainty analysis, health and safety evaluation, site closure strategies, human health and ecological risk assessment, risk management, and risk communication. Members of the risk panel are listed in Section 6.0.

\subsection{PURPOSE}

The UGTA Corrective Action Strategy is carried out sequentially in four stages:

1. The corrective action investigation plan (CAIP);

2. The corrective action investigation (CAI);

3. The corrective action design document/corrective action plan (CADD/CAP); and

4. The closure report (CR). 
As described during the February $19^{\text {th }}$ briefing, the UGTA Project has been able to move through the development of the flow and transport model in the CAI, and currently those model results and data are being evaluated for adequacy for peer review jointly by the Nevada Division of Environmental Protection (NDEP) and DOE-NSO. Pending mutual agreement between NDEP and DOE-NSO, concerning the adequacy of model results and data, the UGTA project would then move forward to the CADD/CAP phase.

The primary objective of the risk panel is to provide DOE-NSO and SNJV with responses and recommendations relative to the following two questions:

Question 1: Has UGTA incorporated risk-based concepts in the project strategy and addressed risk to human health and environment sufficiently to move forward to the next phase of CAU activity, which includes a monitoring program, institutional controls, and a communication plan?

Question 2: IF DOE could explore other risk scenarios, what should they be? Recognize the program is regulated by the FFACO, SDWA, and the UGTA strategy.

\subsection{APPROACH}

To facilitate the risk panel's technical review, the FF-CAU Project Managers provided the panel with 14 references as a basis for formulating its responses to the two questions in addition to the briefing provided at the kick-off meeting.

\subsection{PANEL RESPONSES TO THE TWO QUESTIONS}

Responses from each of the panel members provided as findings are presented in Sections 4.1 to 4.5.

\subsection{Engineering Risk Analysis (Alan Lamont and Lee Glascoe)}

The definition of risk was given at the February 19, 2009 meeting in Las Vegas as the following:

$$
\text { Risk }=\text { probability of hazard multiplied by consequences of hazard. }
$$

Here we discuss from a risk-based perspective the adequacy of the flow and transport analysis in determining the spatial and temporal extent and concentration of groundwater contamination.

The current analysis calculates a set of "risk" contours around Frenchman Flat. Each contour delineates the boundary of an area having a specified probability of exceeding the National Drinking Water Standards for one or more contaminants during the next 1,000 years. This subsection addresses the adequacy of the calculations used to determine these contours. 
The risk contours are based on models of groundwater flow, and contaminant transport. Uncertainty about the extent and timing of contamination arises from uncertainty about the "true" model inputs. These inputs include: the hydraulic heads in the region (and thus uncertainty about the overall directions of flow), the structure of geologic units at the site, and the parameters of the geologic units that govern flow rates and nuclide transport. Monte Carlo analysis has been used to determine the uncertainties in model predictions (i.e., the concentrations of contaminants at various distances and times) that result from the uncertainties in the model inputs.

We do not find any significant concerns with the models themselves. We have been informed that after extensive peer review the models have a sound theoretical basis and have been shown to correctly compute flow and transport, given the correct parameters and boundary conditions. However, we do find concerns about the way that the inputs to models were developed and used in the risk analysis.

Our concerns fall into these areas:

a) The procedure for deriving a contaminant boundary is not operationally defined.

b) Not all of the uncertainties are accounted for in establishing the contaminant boundaries.

c) Some of the procedures used in the analysis are not technically correct for a Monte Carlo risk analysis.

These are discussed below.

\section{The procedure for deriving an overall contaminant boundary is not operationally defined}

Reading the FFACO [6], it seems clear that a single contaminant boundary is to be derived for the site. The FFACO read in part [6,pg 17]:

"...The objective is to analyze and evaluate each UGTA CAU through a combination of data and information collection and evaluation, and modeling groundwater flow and contaminant transport. This analysis will estimate the vertical and horizontal extent of contaminant migration for each CAU in order to predict contaminant boundaries. A contaminant boundary is the model-predicted perimeter, which defines the extent of radionuclide-contaminated groundwater from underground testing above background conditions exceeding the Safe Drinking Water Act (SDWA) standards. The contaminant boundary will be composed of both a perimeter boundary and a lower hydrostratigraphic unit (HSU) boundary. The computer model predicts the location of this boundary within 1,000 years and must do so at a 95\% level of confidence."

From the various documents it is clear that there is significant uncertainty about the structure and connections of the various geologic units underlying the site. The procedure for deriving a contaminant boundary for a given stratigraphic interpretation may be clear. However, each possible 
interpretation leads to a different contaminant boundary. We find no discussion that describes how these different boundaries are to be aggregated into a single boundary. Given that the contaminant boundary is intended to be a primary input to the negotiation for a control boundary, this ambiguity could become a cause of concern in later discussions.

\section{Not all the uncertainties are accounted for}

The current Monte Carlo approach apparently computes probabilities of concentration due to the uncertainty in the transport model alone. For each Monte Carlo analysis it appears the that the flow conditions are held constant, while the transport model parameters are varied (we should note that we could not find an explicit statement to this effect in any of the reports, but that appears to be the case since there is no discussion of deriving probability distributions over the flow model parameters). The uncertainty about the transport model is only one uncertainty in the site. There is also uncertainty about the regional flow and heads, the stratigraphic structure, and the flow model parameters. If we are to follow the conditions laid down in the FFACO, these uncertainties should be accounted for in defining an overall contaminant boundary. However, as noted above, no procedure is stated, so one cannot judge the extent to which the stratigraphic uncertainty is accounted for. The other uncertainties (regional flow and heads and the flow model parameters) simply do not appear to be accounted for. The foundation of the analysis is the interpretation of the stratigraphy and the regional heads and flows. In reviewing the documents we do not find a probabilistic interpretation of the uncertainty in the stratigraphy and the regional heads and flows that could be used in a probabilistic risk analysis. In the absence of this it would be difficult to build a defensible probabilistic risk analysis of the migration and fate of the contaminants.

\section{Some of the procedures used in the analysis are not technically correct}

The analysis uses Monte Carlo simulation to generate probability distributions over model predictions, given the probability distributions over model inputs. If the results are to be meaningful, the probability inputs to the analysis must be defined, and calibrated. It is not clear from the reports provided to us that either of these steps was done adequately. When defining the probability distribution over inputs to a Monte Carlo model, there are two different levels of uncertainty to consider for the hydrostratigraphy. At one level there is variation of a parameter throughout a hydrostratigraphic unit (e.g., the thickness or the hydraulic conductivity) from point to point. This variation can be described as a probability distribution over the properties measured at random locations in a unit. One could, in principle, construct such a probability distribution through extensive sampling of a unit and constructing a histogram of the results. In practice, we use statistical methods to estimate the probability distribution over what value would be measured at a randomly selected sample location. Typically we will estimate the mean, variance, and functional form of the distribution.

The second level of uncertainty is uncertainty about the parameters of the distribution that has been estimated. When we attempt to measure the probability distribution over properties at random locations we generally have relatively little data to estimate the parameters of the distribution. Consequently, we are uncertain about the true mean, variance, and functional form of the distribution. 
Generally, the probability distribution over these three characteristics will be a joint distribution since the probability density function over, for example, the mean will be highly dependent on the estimate of the variance.

Conducting a Monte Carlo analysis requires that we use both types of uncertainty. In this case, it may be the second type of uncertainty (uncertainty over model parameters) that would be most important since the mean of the distribution determines the average properties of a unit, which, to a first approximation, govern the behavior of the unit. Omitting the uncertainty about the parameters of the distribution could lead to substantial errors in the risk analysis.

The documentation that we have received does not discuss adequately how the uncertainties were defined nor how they were estimated. As an example, Reference [13] discusses the first type of uncertainty (spatial uncertainty about the value measured at a random location):

"For example, the frequency distribution for the thickness of a unit at a particular location might be a normal distribution with a mean of $100 \mathrm{~m}(328 \mathrm{ft})$ and a standard deviation of $10 \mathrm{~m}$ $(33 \mathrm{ft})$. This distribution indicates that there is much confidence in a thickness of $100 \mathrm{~m}(328$

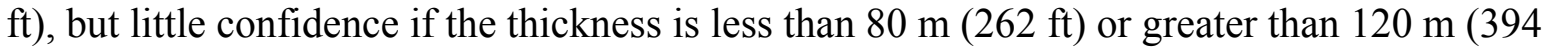
ft)." [Ref 13, pg 3-14]

Reference [11, Appendix E] has an extensive discussion of the estimation of the in-situ distribution over hydraulic conductivity for the units. This estimates the types of distribution and the mean and variance for each geologic unit. However, there is no discussion of the uncertainty in these parameters. Apparently, these estimated distributions are used directly (after adjusting for scaling) in the Monte Carlo analysis. This would be valid if one were to determine that there is, in fact, no significant uncertainty about the means and variances. However, we cannot find that such a claim is made, nor analysis that would support such a claim. It should be noted that the statistical analyses that were used to estimate the types and parameters of the distributions could be extended to provide an estimate of the uncertainty in the parameters.

Reference [12], section 4 discusses the number of samples required in the Monte Carlo analysis. The number of samples is important for determining the reliability of the results of the analysis. If the number of samples is small, there will be large variance in the results of the analysis and one cannot have confidence that the result is correct. The number of samples required depends on the probabilistic dependencies between the input variables, the number of random input variables, and the behavior of the model being sampled. These issues should be discussed and an appropriate sample size should be determined. The report simply quotes the number of samples used in other studies. It is not clear that these other studies are comparable to this study. To demonstrate the "correctness" of the number of samples taken, the report compares the cumulative distribution of the samples to the input distribution. They match. They should match. However, this simply demonstrates that the samples used in the analysis match the marginal distributions. It does not demonstrate that they have adequately sampled the joint distribution. This omission may or may not be a problem. However, this seems to be a naïve approach. This may cause a future reviewer to question the foundations of the analysis. 
Reference [12], section 4 also discusses the scaling of probability distributions due to spatial correlation of properties. This concern is valid. Essentially the problem is this: Data about the stratigraphic units has been taken from samples that represent a relatively small volume. The distribution over these samples will have a variance that is a function of the size of the volume that they represent. However, the model has been divided into elements that are very large compared to the samples, $10 \mathrm{~s}$ of meters on a side. If there is a very low spatial correlation (i.e., samples taken close to each other do not show any statistical correlation), the variation seen in a set of small samples will be averaged out over volumes corresponding to the modeled elements. Ideally, this should be taken into account since the variation in properties when sampled on the scale of the model elements will be smaller that the variation in properties on the scale of the original samples. To account for this, one needs to know the distance over which there is significant correlation within the geologic unit. This distance is a function of the way the unit was formed and its subsequent history. The report can find no good basis for determining such a distance - there simply is not enough data. It is probably not practical to obtain enough data. An arbitrary assumption is needed. And an arbitrary assumption is adequate - scaling the data in this way does not change the mean of the property. And it is the mean that basically determines the behavior. However, the report makes the following assumption [reference 12,pg 4-54]:

As a compromise, an averaging scale of the roughly estimated potential radionuclide transport distance $(0.6 \mathrm{~m} / \mathrm{yr}$ groundwater velocity [SNJV, 2006a] times 1,000 years equivalent to distance $600 \mathrm{~m}$ horizontally and $25 \mathrm{~m}$ vertically; also see the results of Phase I transport distance analysis [SNJV, 2005b]) was used to compute Rv of 0.76 - conceptually, it is more reasonable to average at the scale at which the process that would be affected by the variability occurs

The scale is a function of the rock properties. These do not depend on the rate at water flows through it, or even whether there is water present at all. This logic does not seem to recognize this fact, nor does it seem to appreciate the fundamental statistical issues involved. Such an assertion could lead a future reviewer to question the basis for the analysis.

\subsection{Findings (Jeff Daniels)}

1) Advanced computational flow and transport modeling is performed in order to estimate "mass per unit volume" concentrations of one or more radionuclides in space and time migrating from source locations under the NTS over a 1000-y duration. For purposes of this review, the migration of radionuclides beneath the Frenchman Flat CAU is of interest because this CAU has progressed the furthest with respect to addressing the decision-making process described by the latest version of the proposed UGTA Strategy. Thus, the following finding is pertinent to the groundwater modeling effort.

There is a need to provide a clear and transparent discussion of the details by which the modeling analysis for the FF CAU is used to dismiss or embrace the conclusion that there is a probability or not of significance for radionuclide contaminated ground water in the alluvial aquifer to reach the lower carbonate aquifer (LCA). This issue appears to be of great interest and concern to the State of Nevada 
Division of Environmental Protection (NDEP), based on the size of this aquifer and its use as a water resource, according to interpretation of material provided and in presentations made to the risk panel by the UGTA Leadership.

As stated in earlier Findings by others, a "unify[ing] discussion should enumerate, at a high level, the basic components of the risk analysis [for contaminant migration] ...", such that each component of the assessment is explained and its contribution to a conclusion to accept or reject as reasonable the possibility of flow and transport from the alluvium into the LCA and eventually to a potential receptor population offsite (or not) is obvious to decision makers and stakeholders. This is not the case, based on examination of the "Summary and Conclusions" stated in Stoller-Navarro (2006) [11], which implies there is potential on the southern margins for the tuff confining units to have been thinned by faulting and erosion, "... increasing the potential for hydraulic connection between the shallower material and the lower carbonate aquifer." Even when clarified further, there is no satisfactory unifying and cohesive explanation that links the analytical process (i.e., modeling) to conclusions (LCA contamination reasonableness) and joins both with implications for potential consequence [i.e., future contact with a human receptor based on reasonableness of contamination of LCA and radionuclide(s) at levels exceeding SDWA NPDWRs].

Simplistically, the alluvial aquifer beneath the FF CAU on the NTS is not described as a potential source of water to which individuals might be exposed in the future, and so if it is concluded that there is little or no reasonable likelihood for communication between the alluvial aquifer (the contents of which humans are very unlikely to ever be exposed) and the LCA aquifer (the contents of which human receptors may be exposed), then the potential for human exposure to any radionuclide contaminated groundwater can be eliminated, and so may be any potential health risk. However, the evidence supporting this conclusion (quantitative, qualitative, and/or merely expert judgment) must be transparent, coherent, and easily discoverable for there to be confidence in its reasonableness.

2) It is clear that NDEP will endorse the FFACO Strategy proposed by UGTA, where the metric for assessing consequences of exposure will be the National Primary Drinking Water Regulations (NPDWRs) for Radionuclides exclusively. This is because the NPDWRs are considered enforceable rules for implementing the health-protection intentions of the Safe Drinking Water Act (SDWA) statute. However, the proposed FFACO documentation suggests that these rules are the only health-protective metric by which informed regulatory decisions for protecting the public can and should be made.

- explains that informed regulatory decisions by NSO and NDEP will “ ... protect the public from the risk of radiologically contaminated ground water, and

- the "consequences of exposure will be based on the radiological standards of the SDWA." 
What is not explicitly mentioned, is quite discoverable, and reduces confidence in the use of NPDWRs for radionuclides as the only metric for decision-making purposes. Specifically (see Table 2 appearing in Job, 2009 [17]):

- the NPDWRs for radionuclides are maximum contaminant levels (MCLs), and

- MCLs are the highest level of a contaminant allowed in drinking water, but are not the level at which there is no known or expected risk, because

- although MCLs are set as close to maximum contaminant level goals (MCLGs) ${ }^{1}$ as feasible, they are established taking both best available treatment technology and cost also into consideration.

Therefore, even though the Safe Drinking Water Act (SDWA) does specify that drinking water must comply with the National Primary Drinking Water Regulations (NPDWRs), which include radionuclides, the NPDWRs for radionuclides, especially, infer protection of public health and safety should chronic exposure occur (from ingestion) but do not explicitly express the consequence probability of exposure, particularly to multiple radionuclides simultaneously over time. This lack of transparency and clarity is further compounded by the fact that the NPDWRs for radionuclides are stated in terminology that is neither harmonious, nor easily interpreted by stakeholders, particularly the public (e.g., units of dose for one category of radionuclide, activity concentration for another category, and mass per unit volume for a yet a third category). Consequently, unless parallel calculations of health risk, based at minimum on ingestion exposure, are performed, in addition to those evaluating compliance with NPDWRs, there is no unambiguous quantitative expression of potential health risk by which unified, informed, and defensible decision making regarding negotiation of compliance boundaries can be achieved.

Furthermore, the current situation is truly unique, because the soup of radionuclides potentially available for transport beneath NTS and specifically the FF CAU, regardless of aquifer (about 40 in total, see USDOE, 2006 [5]; Table 4.4, p. 59) is not the "problem" for which the SDWA (NPDWRs for Radionuclides) was intended to be used. In fact, due to the "categories," and number of radionuclides of each category, that may be involved, a combination can actually swamp the ability of the SDWA to protect public health and the environment at a level that conforms to de minimis (negligible) risk (see Daniels and Tompson, 1993 [14], Table 2; and see also Nelson, 2004 [18]). To some degree this is acknowledged in the attempt to predict risk quantitatively from only tritium, which is described in IT, 1996 [2]; USDOE/NVOO, 1997 [4]; and USDOE, 2006 [5]. However, a clearer picture emerges from information provided in the Frenchman Flat Phase II CAU Transport Model [12], which unequivocally acknowledges that multiple radionuclides can contribute to an NPDWR category, and exceedance of one or more categories would be a violation of the standard(s); but this document does not indicate that there is also a possibility that all three categories could achieve their standards, but combined, could exceed levels of reasonable public health risk from ingestion exposure (see Daniels and Tompson, 2003 [1], for explanation of how this could occur).

1. MCLGs are the level of contaminant in drinking water below which there is no known or expected risk to health, but they allow for a margin of safety, and are NONENFORCEABLE public health goals (see footnotes in Table 2 appearing in Job, 2009). 
3) Uncertainty and confidence applicable to both human health exposure and risk modeling, as well as groundwater transport and flow modeling are summarized in IT (1996 [2]; see §3.5.3; §3.5.4; and $\S 4.6$ ) and in Stoller-Navarro (2006 [3]; §ES-6), respectively. See Daniels et al. (1993 and 2000) [14 and 15], as well as Daniels and Tompson, 2003 [1], for examples of methodologies that can be applied for improving quantification of uncertainty associated with exposure and health risk from radionuclide contaminated drinking water.

4) No information provided describes definitions of terms adequately. For example, risk with respect to health consequences is never stated by terminology USEPA considers applicable (see URL: http://www.epa.gov/riskassessmen/basicinformation.htm\#risk):

"the chance of harmful effects to human health or to ecological systems resulting from exposure to an environmental stressor, where a stressor can be any physical, chemical, or biological entity that can induce an adverse response."

Similarly there is absolutely no attempt to frame the discussions of health risk and effects in a manner that would be easily conveyed to the public.

\subsection{Findings (Eileen Mahoney)}

The Corrective Action strategy for UGTA, is stated in the revised FFACO as: "defining perimeter boundaries for each CAU over the next 1000 years which enclose areas potentially exceeding the radiological standards of the Safe Drinking Water Act (SDWA). Confidence in model results will be developed through monitoring studies and the uncertainty in model forecasts will be managed through institutional control of areas of groundwater contamination."

The UGTA Strategy, as stated, is a "compliance" strategy. It meets the requirements of the SDWA to comply with the MCL at the "boundary" of the site. This a strategy that can achieve regulatory acceptance based on compliance with an ARAR. It is not a "risk-based" strategy, which requires an assessment of site risks under current and reasonable future conditions (i.e., $25 \mathrm{y}, 50 \mathrm{y}, 100 \mathrm{y}$ ) utilizing published risk assessment methodology, and which provides an understanding of the risks posed by the groundwater at the site to any potential receptors under realistic current and future exposure scenarios.

The MCL does not provide a risk equivalent value (i.e., what is the risk at the MCL concentration). This risk equivalent can, and should be calculated to confirm that the MCL(s) is adequate to be protective of human health at the site. 
While the UGTA compliance strategy meets regulatory requirements (if all COC MCLs are met), it has not adequately assessed risks at the site needed to support a successful communication plan, institutional controls, or monitoring program. The rationale for this conclusion is presented below.

Implicit in questions 1 and 2, is the need to find a solution which will move the process forward to a successful agreement on the CADD and CAP for Frenchman Flat. In order to answer questions 1 and 2 regarding human health risks, it is important to understand that the needs of all stakeholders must be met in order to move forward with agreement and success. The stakeholders at the site are DOE, NDEP, and the public. This is clearly stated in the FFACO (USDOE, 2008). Each stakeholder has a different set of requirements with regards to human health risk, and while there is some overlap among them, there are also requirements that are unique to each. As stated in a range of documents the needs of each are outlined here.

DOE: The NNSA/NSO and DOE have stated the position that the Safe Drinking Water Act (SDWA) maximum concentration levels are the standards to which the project will follow. Recent interactions with NDEP indicate they support the SDWA standard. Both NNSA/NSO and NDEP are committed to meeting these standards (Marutzky, 2009). The SDWA strategy is a compliance strategy which satisfies the regulatory requirements for Frenchman Flat, in conjunction with DOE's intent to eliminate exposures to any groundwater which exceeds SDWA by controlling access. It may benefit DOE to develop a methodology for characterizing site risks which adheres to industry standards and can be applied across all CAUs at NTS. There may be CAUs for which the current approach of limiting access is not feasible, and the current SDWA strategy is limited in that it does not provide any information on risks at the site which could be used to determine additional options available to protect human health when restriction is less feasible.

NDEP: NDEP is requesting an assessment of human health risks which will enable the siting of monitoring wells in the areas of highest risk to off-site residents. In order to do this, risks must be calculated using EPA methodology $\left(10^{-6}\right.$ to $\left.10^{-4}\right)$ (USEPA 1989 [10]) for off-site residents under current conditions and under realistic future timeframes (e.g., $25 \mathrm{yr}, 50 \mathrm{yr}, 100 \mathrm{yr}, 1000 \mathrm{yr}$ ). This should include a risk assessment of all COCs and a cumulative risk value, which can serve as the basis of NDEP's agreement for the siting of monitoring wells to protect the areas of greatest potential risk.

Additionally, NDEP expresses that their primary concern is with the lower Carbonate aquifer which is a critical resource for the state and its residents, as the source of drinking water. If possible, the deep aquifer should be assessed separately, using outputs from the groundwater modeling program to calculate human health risks for all COCs in this critical aquifer. It appears that this is the most critical information that NDEP requires to make decisions about the safety of this drinking water source currently and to protect this important resource in the future (again at realistic time frames 25, $50,100 \mathrm{y}$ ). A quantitative assessment of risks from the lower Carbonate aquifer should be conducted, to support NDEP's need to understand the impacts on and protect this aquifer. 
PUBLIC: The public requires an understanding of potential off-site risks under current and potential future conditions, based on exposures to drinking water off-site. The most scientifically acceptable method for doing this is using the USEPA-published methodology for estimating human health risks (USEPA 1989 [10]). The output of this risk assessment will consider cumulative risks for all COCs in groundwater at off-site locations, for groundwater which may serve as a source of drinking water. Additionally, a Conceptual Site Model should be prepared for the FFCAU which would identify the aquifers of concern and potential exposures to them. An assessment of risks from potential exposures to the lower Carbonate aquifer would provide valuable health risk information to the public.

\section{Question 1: \\ Monitoring plan -}

Conclusion: The CADD will better meet NDEP's concerns about placement of monitoring wells if off-site risks are presented clearly (for the sum of COCs) — at different time intervals (present, 25y, $50 \mathrm{y}, 100 \mathrm{y}, 1000 \mathrm{y}$ ) and monitoring wells can be placed off site at sites representing worst case sites for risk.

Institutional Controls - institutional controls should be dependent on future potential uses of the site, and associated risks. Absent that, the only option for "institutional controls" is complete banning of use, which can be done on federal land. However if there is potential for off-site impact, then an understanding of risks would better inform the process of well siting.

Conclusion: If DOE wants to limit exposure to zero, That would satisfy regulatory requirements. It appears however that NDEP would be better satisfied with a solution that can characterize risks for off-site residents. This is not addressed with the current plan.

\section{Communication Plan}

The communication plan needs to meet the needs of all stakeholders: DOE, NDEP, and the PUBLIC. The current strategy will not meet the needs of DOE, NDEP or the PUBLIC.

I will address the needs for the communication plan for the PUBLIC, as they are the greatest. The questions which will need to be answered are:

- What are the risks to the public -(off-site groundwater) under current conditions?

- What are the risks in the future - 10 years, 25 years, 50 years, 100 years?

- How will DOE protect the public from these risks? Provide specific plans for specific scenarios?

In order to be prepared to answer these questions, a risk assessment should be completed, which summarizes risks for all COCs in groundwater, using the standard EPA methodology, which can utilize data generated from the groundwater modeling effort. This will provide us with a clear understanding of risks at the off-site areas of potential impact in the present and in realistic future 
time frames and for different aquifers, as exposures to each will vary. The public needs to understand the process, and generally has faith in EPA methodology which has been utilized extensively across the country at thousands of sites. It brings credibility to the process that has been validated by EPA, which is generally trusted. Details of potential exposure scenarios and pathways can be defined and agreed upon as the work progresses. This will improve DOE's ability to effectively communicate site risks to the public.

Additionally, it will be necessary to collect some "real" data and be able to communicate some "real" results to the public, even if this is an iterative process, that at first presents modeled data risks, but follows up with real data risks, as soon as they are available — or at least have sentinel wells placed in the most appropriate places to be protective of off-site residents. This also supports the need for off site wells in areas of greatest potential impact to the public.

Conclusion: The current plan is not adequate to proceed with a communication plan for the PUBLIC. More specific risk assessment information will be necessary for this. The risk assessment, in conjunction with the current plan to use SDWA standards will also help to satisfy the NDEP, which at this point seems to be asking for more information on risks, specifically related to the lower Carbonate aquifer. UGTA NDEP Comment Responses (page 3) states that risks are not adequately characterized. The FFACO App VI states the need for public involvement. (USDOE, FFACO App VI, 2008 section 1.3.1, page 4-5 [6]). The FFACO App VI states that risks should be assessed when multiple contaminants are present (instead of standards), page 7 [6].

\section{Question \#2:}

\section{If DOE could explore other risk scenarios, what would they be?}

In order to determine which additional exposure scenarios should be assessed at Frenchman Flat CAU, a Conceptual Site Model(CSM) for Human Health Risks should be prepared, which reflects the site-specific conditions at FFCAU.

The primary consideration for additional exposure scenarios should be for off-site (off federal land) uses of, and potential exposures to, the three aquifers. To which aquifer(s) are residents likely to have exposure? Potential additional scenarios for off-site federal land have been presented in the previous risk assessment (IT , 1996 [2]). These included use of BLM lands for grazing, mining, and recreation, as cited in USDOE 2006 [5], END STATE VISION. Therefore, these are potential additional scenarios for consideration.

Findings Regarding Ecological risks - Ecological risks have not been addressed in the FFACO. These should be assessed. Start with the IT report which assessed ecological risks. 


\subsection{Findings (Lynn Kidman)}

The FFACO clearly states that the boundary will be established based on the farthest extent of contamination exceeding the action levels in any aquifer. In addition, based on the following assumptions, there is no complete pathway to a receptor and no risk to be assessed for this population:

- the US government will prevent uncontrolled access to all groundwater within the corrective action boundary

- the boundary will be established based on the SDWA standards and the $95^{\text {th }}$ percentile of model results

- the SDWA standards are protective

- the $95^{\text {th }}$ percentile of model results are protective

The risk to a receptor then becomes the risk that one or more of the assumptions are not valid. With regards the use of MCLs in the UGTA strategy, it may be useful to see what effect the risk equivalent concentrations may have on boundaries so that the project would have that information for communication purposes.

\subsection{Findings (Mary Picel)}

In responding to Question \#1, this reviewer assumes that the output from the transport model would be adequate in determining a contaminant boundary for the purposes of negotiations between the DOE/NSO and NDEP for a compliance boundary consistent with the requirements specified in the FFACO. Therefore, the focus of this review was on determining whether the UGTA strategy as described in the FFACO adequately address potential human health or ecological impacts.

By using SDWA standards or MCLs as the basis for forecasting the contaminant boundary for negotiating a compliance boundary, the UGTA strategy for Frenchman Flat limits access to radionuclide concentrations in groundwater to levels at or below the maximum levels that EPA has determined to be acceptable in drinking water systems in the country. This is clearly a conservative approach. MCLs have been promulgated by the EPA for tritium $(20,000 \mathrm{pCi} / \mathrm{L})$, strontium-90 $(8 \mathrm{pCi} / \mathrm{L})$, uranium $(30 \mu \mathrm{g} / \mathrm{l})$, radium 226 and radium 228 combined $(5 \mathrm{pCi} / \mathrm{L})$, gross alpha $(15 \mathrm{pCi} / \mathrm{L})$, and beta and photon emitters (4 mrem/yr). The combined dose from multiple beta/photon emitters cannot exceed the $4 \mathrm{mrem} / \mathrm{yr}$ standard, which is addressed by using a sum of ratios. In providing perspective as to the risk equivalence of the dose standards for radionuclides, the EPA has indicated that a dose of $15 \mathrm{mrem} / \mathrm{yr}$ equates to approximately $3 \times 10^{-4}$ increased lifetime risk [8]; this places the $4 \mathrm{mrem} / \mathrm{yr}$ standard for beta and photon emitters to equate to about $1 \times 10^{-4}$.

Based on the information received at the briefing, the transport model accounts for all radionuclides included in the source term information provided by Bowen (see Table in DOE's End State Vision Report [5]). Radioactive decay and ingrowth have also been taken into account. This approach in 
identifying the radionuclides of concern should result in transport model outputs that address all critical radionuclides of concern.

The conceptual site model (CSM) presented for the UGTA CAUs in the End State Vision Report [5] indicates that a completed exposure pathway to potential groundwater contamination does not exist for human and ecological receptors under current land use conditions. A Frenchman Flat - specific CSM would be most useful for re-iterating the lack of completed exposure pathways reflecting current and future land use conditions, as the case may be. Further, the UGTA strategy incorporates the use of institutional controls to restrict access to groundwater within the compliance boundary (including any off-site areas), thereby eliminating or minimizing the potential for exposure to contaminated groundwater. Monitoring provides field data as continuous verification of the protectiveness of site conditions.

Risk calculations for tritium are discussed in an IT Report [2]. The deep aquifers involved in this CAU limits the ability to cost-effectively collect data for conducting a baseline risk assessment. In addition, the FFACO agreement to use SDWA standards as the compliance metric alleviates the need to develop risk-based end-points. However, risk calculations can be performed using transport model results, particularly for the areas outside the boundary and/or outside the institutional controls area. Once monitoring data is obtained from the compliance boundary, further risk calculations can be done based on these field data. This information would be most useful for communicating the conditions at these areas.

In conclusion, this reviewer believes that once the transport model outputs have been determined to be adequate, the project should be able to move forward to the CADD/CAP phase to negotiate the compliance boundary. In parallel to the negotiations, an additional report or white paper could be prepared to collate and update risk information for the Frenchman Flat CAU. Implementation of the monitoring network, development of appropriate institutional control instruments (e.g., in determining active versus passive controls), and the preparation of a transparent communication plan can be aided by the collection of risk information that would be in this new report.

As for Question \#2, the Frenchman Flat CAU CSM suggested above should help identify other receptor scenarios that might be useful.

\subsection{RECOMMENDATIONS}

Sections 5.1 to 5.5 discuss recommendations provided by the panel members.

\subsection{Recommendations (Alan Lamont and Lee Glascoe)}

\section{Recommendations for the risk assessment}

This project benefits from a wealth of detailed analysis by technical participants of the highest caliber using state-of-the-art numerical and experimental facilities. Many disparate analyses have been done 
to understand the flow and transport at Frenchman Flat with a goal of making a set of best estimates rather than assessing the overall uncertainty of contaminant migration - the basis of a defensible risk assessment.

Due to the complexity of all the uncertainties it is not clear that a completely analytic risk analysis is feasible for this particular site (though it may be for other CAUs such as Pahute Mesa). If the project is able to make a quantitative assessment of the uncertainties in the fundamental uncertainties in the stratigraphy and regional heads and flows, then a quantitative risk analysis could be completed. However, if this is impractical a conservative and defensible bounding risk analysis may be warranted. Such an approach would be based on straightforward and conservative bounding interpretations of the analyses and data available.

Currently, it is difficult to see how the extensive analyses done for Frenchman Flat have been assembled and interpreted for the risk analysis - the reader must wade through discussions of the details of analyses looking for the elements of a correct analysis. For example, it is difficult to determine that the flow models were not part of the Monte Carlo analysis. It s only after reading the sections on the Monte Carlo analysis and noting that the flow parameters are not discussed that one can infer that the flow model was not included (in fact, it is still not completely clear how the flow models were actually used). Editorially, it appears that the original discussions in the reports were written to describe statistical analyses that were intended to make a best estimate of the material properties and their distributions. This is, of course, a perfectly reasonable approach. However, such an approach tends to de-emphasize the uncertainties in the estimates. On the other hand, a risk analysis needs to highlight the uncertainties in those estimates. Even if the analysis cannot quantify the uncertainties in, say, stratigraphy or boundary heads, it can still provide a well organized discussion of the range of possibilities, perhaps with some judgments as to what is more or less likely, along with the basis for that judgment. Before proceeding, the existing analyses should be unified into a comprehensive understanding of the most important uncertainties that drive contaminant migration. The unified discussion should enumerate, at a high level, the basic components of a risk analysis for this site (i.e., uncertainties about stratigraphic, flow parameters, etc.) and describe how each of those components was addressed. It will undoubtedly be impractical to analyze each component of the uncertainty analysis in a textbook-correct way-approximations, bounding conditions, and professional judgment will probably be needed. Further fieldwork and testing, even if were feasible, would probably not contribute significantly to our understanding. Instead, the discussion should describe clearly what was actually done in the risk analysis, and what was not done. It should also explain why the approach taken is adequate for this analysis. This would give more confidence that the uncertainty analysis is correct and useful for establishing controls and a monitoring program. 


\subsection{Recommendations (Jeff Daniels)}

Question 1: Has UGTA incorporated risk-based concepts in the project strategy and addressed risk to human health and environment sufficiently to move forward to the next phase of CAU activity, which includes a monitoring program, institutional controls, and a communication plan?

\section{Given}

1) the soup of about 40 radionuclides (see USDOE, 2006; Table 4.4, p. 59) that could migrate under the NTS and from the FF CAU in particular (unless sound engineering judgment, conveyed transparently and defensibly, proves transport modeling of fewer isotopes in this inventory will be sufficient);

2) that it cannot be ruled out as unreasonable that one or more of these same radionuclides could eventually reach the aquifer of greatest concern beneath the alluvium and tuff at the FF CAU (the lower carbonate aquifer, LCA, see Stoller-Navarro, 2006); and

3 ) the lack of any comprehensive effort to most effectively identify the magnitude and location of health risks from realistic exposure pathways to multiple radionuclides at a specific location offsite, where migration may be forecast,

it would be an undefensible leap of faith to unequivocally conclude the risk to human health and environment is addressed sufficiently for purposes of decision making and risk communication. Therefore, without further analysis or improved explanation that addresses these issues responsibly, it is not recommended to move forward to the next phase of the CAU activity: including monitoring, establishing institutional controls, and proceeding with a communication plan

Alternatively, under the current rubric the United States Department of Energy (USDOE/NNSA/NSO) may wish to state unequivocally and unconditionally there will be NO EXPOSURE to ground water containing any radionuclide (introduced as a result of weapon testing) or its progeny in perpetuity (i.e., now or ever), either onsite or offsite the FF-CAU of the NTS. Under these circumstances, wherever radionuclides from weapon testing on FF CAU are modeled or detected in ground water, exposure would be denied, and any adverse health risk would be eliminated completely. However, it is likely to be more cost effective and credible for DOE/NNSA/NSO to direct its contractors to actually compute risk based on different metrics (e.g., SDWA and also health risk from specific, realistic exposure scenarios). Of course, this will take additional effort and some added computer time, but it will be helpful for addressing any already elevated unrealistic public perception and "outrage" about radionuclides generally and in ground water (see Fitzgerald, 2009 [16], for summary of consequences of public "outrage", including conducting of long-term monitoring, and deciding "how clean is clean?"), and will more satisfactorily identify where acceptable risk can be found and unacceptable risk could be encountered. It will also help with negotiating the most sensible compliance boundary.

Question 2: IF DOE could explore other risk scenarios, what should they be? Recognize the program is regulated by the FFACO, SDWA, and the UGTA strategy. 
There is no real reason for USDOE/NNSA/NSO not to determine realistic exposure scenarios for populations that may be exposed to radionuclide migration from the NTS, and in this case from the FF CAU. The most likely exposure scenarios can be defined based on climate and terrain. Within such exposure scenarios, exposure and dose parameters can be assessed probabilistically using Monte Carlo analyses (see Daniels et al., 1993 [14] and 2000 [15] and also Daniels and Tompson, 2003 [1]). It is factually incorrect to assume that only the SDWA NPDWRs for radionuclides would be applicable as the only strategy for decision making, even though they are the only enforceable standards. The UGTA Strategy could benefit from calculations involving realistic health risk (even if only from drinking water exposure), especially because this would harmonize the disparate metrics currently used by the SDWA NPDWRs for Radionuclides:-alpha-a = activity based (not to exceed $15 \mathrm{pCi} / \mathrm{L}$ ); beta-b and photon and gamma-g = dose based (not to exceed $4 \mathrm{mrem} / \mathrm{y}$ ); and uranium $=$ mass based $(15 \mathrm{mg} / \mathrm{L})$. Only the standard for uranium (an element with long-lived naturally occurring alpha emitting isotopes) was developed recently, and for all other radionuclides the NPDWRs were derived without regard to modern dosimetry, and were never, ever intended to address the potential combination of radionuclides that could be present simultaneously, and in multiple emission classes and even toxicology, following a nuclear detonation in geologic material near, at, or below the water table (and represented by unburned fuel, fission products, and neutron activation products). Additionally, it is evident the standards (i.e., NDPWRs or MCLs for radionuclides) are not the level at which there is no known or expected health risk. For these reasons, the contamination of ground water by multiple radionuclides introduced anthropogenically at the UGTA CAUs, including the FF CAU, constitutes a regulatory challenge that is unprecedented, distinctive, and extraordinarily complicated. Thus, decision making that is realistic, cost-effective, and protective of public health and the environment will require solutions that are innovative and robust and yield results that are defensible and promote public confidence.

Indeed it may cost additional time to perform a health-based exposure and risk analysis to evaluate health risk along with compliance to SDWA "standards", but in terms of ensuring and communicating protection of public health and the environment it will be well worth the effort. Most importantly, in the long run this effort will advance risk communication, which is incredibly important for moving forward with monitoring and assuaging poorly conceived, unfounded misconceptions by stakeholders, especially skeptical about a 1000-y time horizon. This effort may also lead to cost savings involving monitoring and establishing the most reasonable FF-CAU compliance boundary.

In answering questions 1 and 2 in this manner, it will be possible to move forward and develop realistic exposure scenarios that will lead to practical estimates of health risk and quantification of ecological damage [which was only mentioned qualitatively, with respect to a threshold level that could be protective of the desert pupfish (IT, 1996 [2]), and at minimum requires elaboration]. This will then make it possible to move forward with monitoring and effective communication plans.

\subsection{Recommendations (Eileen Mahoney)}

Continue with the SDWA/compliance boundary approach as a regulatory requirement, but supplement this with a site-specific risk assessment, as a means to provide more information to the impacted parties, and inform the decision-making process regarding monitoring well siting and 
support a communication plan. It would be advantageous to convert the MCLs to a risk equivalent in order to provide a risk value to the compliance boundary, which could be communicated on a risk basis, as opposed to the current strategy, which is a compliance-based approach.

Recommend a separate Conceptual Site Model for each CAU, to define receptors and scenarios for each.

Conduct EPA risk assessment (10-6-10-4) using model outputs, based on the Conceptual Site Model, in realistic time frames $(10,25,50,100 \mathrm{y})$. Consider different aquifers and off-site residents.

The risk documents and the FFACO should be reviewed in detail, and the differences and similarities should be highlighted, with a recommendation on how best to reconcile the differences going forward.

We should look at risks for separate aquifers. NDEP is most interested in the Carbonate aquifer which has had little impact. Things may be better than we are predicting when the risks for this aquifer are isolated.

Eco risks need to be brought in here - the risk assessment (IT) assessed eco risks and may be helpful in this regard.

A risk panel member should write, or at least edit, the sections in the FFACA related to risk, to ensure consistency with standard terms and definitions. Use of terminology such as "risk-based" to describe the SDWA compliance strategy is inaccurate.

\subsection{Recommendation (Lynn Kidman)}

It may be useful to determine what effect the risk based concentrations may have on boundaries as compared to the MCLs. This additional information would be useful in providing perspective for communication purposes.

\subsection{Recommendation (Mary Picel)}

A report or white paper specific to the Frenchman Flat UGTA CAU could be prepared to collate the risk assessment components currently found in various project reports. This can be done by reference to these various reports. Additional calculations to compare MCL equivalent concentrations to 10-4 equivalent concentrations could be performed to provide perspective with regards the level of protection afforded by the MCLs. It is expected that the concentrations would be generally similar. A boundary based on 10-4 risk can be forecasted if the concentrations are determined to be sufficiently different.

A Frenchman Flat CAU specific CSM could be used to determine if an ecological risk assessment is needed or not. The primary objective of this new report would be to collate, update, and augment risk 
information to support the corrective action strategy for the FF-UGTA CAU. Information embodied in this new report could be used to support upcoming CAU activities including the following: (1) determination of what-if scenarios for contingency planning and for interpreting monitoring well data or results from the contaminant/compliance boundaries; (2) the development of risk-based institutional controls; and most importantly (3) for facilitating risk communication with NDEP, the public and other stakeholders.

The following components are recommended to be included in this new report:

\section{1) List of the radionuclides of concern (all items bulleted can be extracted from existing reports [i.e., transport model reports])}

- Present source term (extract from or refer to Table 4.4 in the RBES report);

- Discuss any screening from the source term if a screening was conducted and provide rationale for radionuclides screened in or out;

- Present the final list of radionuclides addressed in the transport model. Also, present the list of radionuclides that would be carried forward in the CADD/CAP phase if different from the final transport model list.

\section{2) Develop a CSM for the FF-UGTA CAU}

- $\quad$ Provide a more FF-UGTA CAU specific CSM than that included in the RBES report.

- Both current and reasonably foreseeable land uses on site and off site should be addressed in this CSM. Ecological resources can also be incorporated into this CSM or a separate CSM can be prepared, as appropriate. This CSM can then be used as the basis for supporting the identification of the aquifer of concern, potential pathways, and potential receptors, if any.

By developing the CSM(s) recommended here, other human health risk scenarios appropriate to current and future land uses would be identified and documented providing the answer to Question \#2. Potential additional scenarios for off-site federal land have been presented in the previous risk assessment [2]. These included use of BLM lands for grazing, mining, and recreation, as cited in the Risk Based End State report [5]. These maybe potential additional scenarios for consideration but may be more relevant to potentially contaminated media other than groundwater.

This CSM would also be the vehicle to determine whether an ecological risk assessment is needed or not. This CSM could demonstrate that a completed pathway to ecological resources in the area is not likely; and therefore, an ecological risk assessment would not be needed. 


\section{3) Calculate concentrations equivalent to 10-4 risk for the radionuclides of concern.}

- Risk coefficients provided in FGR 13 [9] could be used to calculate the radionuclide concentrations equivalent to 10-4 risk. This calculation can be accomplished using a simple spread sheet.

- Results from this calculation could be used to compare against the MCLs.

- A risk-based boundary could be considered if the results vary sufficiently.

\section{4) Calculate risk at the contaminant boundary using transport model output}

- Calculate combined risk using transport model outputs (in terms of radionuclide concentrations forecasted) for the ingestion (of water) pathway. Use 2 liter/day intake for 365 days/yr for 70 year duration and the slope factors provided in FGR 13

- These calculations can be performed for various time frames (the transport model output/information can guide in determining which time frames are meaningful, e.g., peak doses for critical contaminants)

\subsection{RISK EVALUATION PANEL}

(1) Jeffrey I. Daniels, D.Env., Consultant; Human-Health and Ecological Risk Analysis, Management, and Communication, Radionuclide Dose Reconstruction

(2) Lee Glascoe, PhD, PE. Staff research engineer and group leader of the Applied Statistics and Economics Group of Lawrence Livermore National Laboratory; Fluid dynamics and thermal/constituent transport; Uncertainty quantification.

(3) Lynn Kidman, PhD, Stoller-Navarro Joint Venture, Remedial project strategies, planning, and management.

(4) Alan Lamont, PhD., Lawrence Livermore National Laboratory; Probabilistic analysis of security systems; Economics of energy systems; Risk and decision analysis.

(5) Eileen Mahoney, PhD., Mahoney Associates; Human health risk assessment of hazardous waste sites under CERCLA, RCRA and state statutes; risk-based remedial design; agency negotiations.

(6) Mary Picel, M.S., (Panel Lead); Program Manager for Risk Assessment and Waste Management, Argonne National Laboratory; Human health risk assessment/risk management; remedial action planning and decisions, waste management, site closure strategies and implementation. 


\subsection{REFERENCES}

1. Daniels, J.I., and A.F.B. Tompson, 2003.

TECHNICAL BASIS FOR ALSO USING HEALTH-RISK ASSESSMENT TO ESTABLISH CONTAMINANT BOUNDARIES FOR CORRECTIVE ACTION UNITS (CAUS) OF THE UNDERGROUND TEST AREA (UGTA) AT THE NEVADA TEST SITE (NTS), Lawrence Livermore National Laboratory, Livermore, CA, UCRL-TR-201702 (November 2003; pp. 28).

\section{IT Corporation, 1996.}

Underground Test Area Subproject Phase I Data Analysis Task-Volume VIII: RISK ASSESSMENT DOCUMENTATION PACKAGE, prepared for United States Department of Energy, Nevada Site Office, Las Vegas, NV, by IT Corporation Las Vegas, NV, ITLV/10972-181 (December 1996; pp. 154).

3. Stoller-Navarro, 2006.

EXECUTIVE SUMMARY-PHASE II GROUNDWATER FLOW MODEL OF CORRECTIVE ACTION UNIT 98: FRENCHMAN FLAT, NEVADA TEST SITE, NYE COUNTY, NEVADA, prepared for the United States Department of Energy, Nevada Site Office, Las Vegas, NV, by Stoller-Navarro, Las Vegas, NV, S-N/99205-074; Rev. 0 (May 2006; pp. 36).

4. United States Department of Energy, Nevada Operations Office [USDOE/NV00], 1997. Regional groundwater flow and tritium transport modeling and risk assessment of the underground test area, nevada test site, Nevada, prepared from data analysis activities conducted during the regional investigation of the Underground Test Area Subproject by IT Corporation, Tetra Tech, Inc.; GeoTrans, Inc.; and Daniel B. Stephens Corporation and cooperative efforts of many other participants, DOE/NV-477 (UC-700; October 1997; pp. 396).

5. United States Department of Energy [USDOE], 2006.

U.S. Department of Energy, Nevada Test Site Environmental Management END STATE VISION, United States Department of Energy, Office of Scientific and Technical Information, Oak Ridge, TN, DOE/NV--958 (January 2006; pp. 98).

6. United States Department of Energy [USDOE], State of Nevada Department of Environmental Protection [NDEP], and United States Department of Defense [USDOD], 2008.

Federal Facilities Agreement and Consent Order (FFACO): Appendix VI—Corrective Action Strategy, United States Department of Energy, United States Department of Energy, Nevada Site Office, Las Vegas, NV (AS AGREED, February 2008; pp. 44).

7. Stoller-Navarro, 2004.

Phase II GRoundwater Flow AND CONTAMINANT TRANSPORT MOdEL OF CORRECTIVE ACtion Unit 98: Frenchman Flat, Nevada Test Site, Nye CounTy, NEVADA, prepared for the United States Department of Energy, Nevada Site Office, Las Vegas, NV, by Stoller-Navarro, Las Vegas, NV, S-N/99205-032; Rev. 0 (December 2004).

8. U.S. Environmental Protection Agency, 1997.

Establishment of Cleanup Levels for CERCLA Sites with Radioactive Contamination, OSWER No. 9200.4-18, April 22. 
9. U.S. Environmental Protection Agency, 1999.

Cancer Risk Coefficients for Environmental Exposure to radionuclides, Federal Guidance Report No. 13, Office of Radiation and Indoor Air, EPA 402-R-99-001, September.

10. U.S. Environmental Protection Agency, 1989.

Risk Assessment Guidance for Superfund Volume 1; Human Health Evaluation Manual, Part A.

11. Stoller-Navarro, 2006.

Phase II Groundwater Flow Model of Corrective Action Unit 98: Frenchman Flat, Nevada Test Site, Nye County, Nevada", S-N/99205--074, Revision No.: 0, May 2006.

12. Stoller-Navarro, 2009.

Phase II Transport Model of Corrective Action Unit 98: Frenchman Flat, Nevada Test Site, Nye County, Nevada, S-N/99205--122. Las Vegas, NV.

13. United States Department of Energy [USDOE 1997.

Regional Groundwater Flow and Tritium Transport Modeling and Risk Assessment of the Underground Test Area, Nevada Test Site, Nevada, DOE/NV--477 UC-700, October 1997

14. Daniels, J.I., R. Andricevic, L.R. Anspaugh and R.L. Jacobson, 1993.

"Risk-Based Screening Analysis of Ground Water Contaminated by Radionuclides Introduced at the Nevada Test Site (NTS)," in PILOT STUDY RISK ASSESSMENT FOR SELECTED PROBLEMS AT THE NEVADA TEST SITE (NTS), J.I. Daniels, Ed., Lawrence Livermore National Laboratory, Livermore, CA, UCRL-LR-113891, pp. 69-97.

15. Daniels, J.I., K.T. Bogen, and L.C. Hall, 2000.

Analysis of Uncertainty and Variability in Exposure to Characterize Risk: Case Study Involving Trichloroethylene Groundwater Contamination at Beale Air Force Base in California," WATER, AIR, SOIL POLLUT. 123, 273-298.

16. Fitzgerald, J., 2009.

"One Regulatory Perspective on the Vapor Intrusion Pathway,"

GROUND WATER MONIT. REM. 29(1), 51-52 (Winter 2009).

17. Joh, C. [2009].

"Radionuclides Responsible for the Third Highest Water Quality Violations in Ground Water Supply Systems," GROUND WATER MONIT. REM. 29(1), 42-44.

(Winter 2009).

18. Nelson, N., 2004.

Health Effects: Ionizing Radiation, Powerpoint Presentation given as part of the Radionuclides Web Cast, Office of Radiation and Indoor Air, Center for Science and Risk Assessment, United States Environmental Protection Agency, Washington, DC (June 29, 2004; URL:

http://www.epa.ogv/safewater/dwa/rules.html, last updated Thursday, 6 March 2008). 


\section{Appendix B}

UGTA Subproject Responses to External Risk Review Panel Findings

(3 Pages) 


\section{UGTA SUBPROJECT RESPONSES TO THE REPORT BY THE RISK REVIEW PANEL FOR THE FRENCHMAN FLAT CORRECTIVE ACTION UNIT}

\section{Introduction}

The external risk review panel (Review Panel) for the Frenchman Flat Corrective Action Unit (CAU) of the Underground Testing Area (UGTA) at the Nevada Test (NTS) provided a final report of their technical review of risk-related studies for the Frenchman Flat CAU. The panel responded to review questions submitted by the Nevada Site Office (NSO) UGTA Subproject and provided both individual and summary recommendations. The review was based on information presented in combined technical briefings by the UGTA Subproject and 14 reference documents provided to the review panel. This brief summary is written as an appendix attachment to the report by the Review Panel and has three objectives:

1. Formally accept the report by the Review Panel as the completion activity of the study,

2. Provide perceptions with respect to the UGTA program of the report content and recommendations, and

3. Clarify and/or correct minor technical aspects of the report.

The UGTA Subproject appreciates the thoughtful insights and recommendations of all members of the Review Panel and the large quantity of information they assimilated through evaluations of technical reports.

The Review Panel presented useful technical perspectives for a very complex program and their recommendations will aid the UGTA Subproject in executing the UGTA strategy and in presenting materials to future technical audiences. The over-riding benefit of the Review Panel report is the recommendation that a future report be prepared which collates existing risk assessment information in UGTA reports and presents additional risk-based calculations. They suggest the report should include:

1. A better defined conceptual site model of human health risks for the Frenchman Flat CAU,

2. Identification of potential exposure scenarios which are applicable to the setting of the Frenchman Flat $\mathrm{CAU}$, and

3. Identification of model predicted radionuclide concentrations for the Frenchman Flat CAU at selected time intervals and locations and conversion of the concentrations to doses using metrics consistent with the regulations and current practices of the U.S. Environmental Protection Agency.

These assessments would supplement existing UGTA model results using requirements established in the Safe Drinking Water Act (SDWA). The NNSA NSO agrees with this recommendation and the required studies are the subject of this report. 


\section{Overview of UGTA Subproject Clarifications}

1) The UGTA program strategy is a decision-based approach which uses combined and integrated approaches of modeling/characterization, monitoring and institutional control to resolve regulatory requirements. The strategy incorporates risk concepts in multiple aspects of the UGTA stages but the pragmatism of achieving regulatory goals does not allow the program to follow a fully risk-based approach. The UGTA Subproject, through FFACO agreement with the Nevada Department of Environmental Protection (NDEP), substitutes the requirements of the SDWA for the scenario development and exposure assessment parts of a risk-based approach.

2) The UGTA Subproject assumes the requirements of the SDWA are a reasonable approach to protecting the public because the approach assumes protection equivalent to a municipal water supply and a probability of 1 for the exposure metrics used in the requirements of the SDWA. The areas of radionuclide contamination at and near the NTS are far removed from population centers using municipal water supplies and the remote setting of the NTS in an arid desert climate reduces the probability of a future scenario of equivalency to a municipal water supply to much less than 1.

3) The UGTA Subproject asked the Review Panel whether the risk protection of the public under the UGTA strategy was adequate to move to the CADD/CAP stage of the UGTA strategy, not whether all standard aspects of a risk assessment process are included in the UGTA strategy.

4) The Review Panel was not expected to review technical aspects of the flow and transport modeling conducted for the Frenchman Flat CAU. All information required for such a review was not provided to the panel and including all the required information would have greatly lengthened the time required for the risk review.

5) The Review Panel was not requested to conduct a review of the provisions and suitability of the SDWA. The SDWA is a regulation developed and promulgated by the U.S. Environmental Protection Agency and is used in the UGTA strategy through agreements established in the FFACO.

\section{Specific UGTA Subproject Clarifications/Corrections}

1. Page 4, paragraph 3: A single contaminant boundary was not derived for the Frenchman Flat transport modeling. Ensembles of contaminant boundaries were developed from the transport modeling using a matrix of multiple alternative models of the hydrogeologic framework, boundary and flux conditions, and recharge with acceptable calibrations required for each set of alternatives models. This is described in Chapter 6 (Conceptual Model Uncertainty Analysis) of the Frenchman Flat Flow model (Reference 11 in the Review Panel Report) and in Chapter 7 (Contaminant Boundary Calculation) of the Transport Document (Reference 12). Methods of aggregation of alternative contaminant boundaries are described in Chapter 12 of the transport document (Quantifying the Impacts of Model Uncertainty on Groundwater Model Prediction) in the Transport Document (Reference 12).

2. Page 5, first full paragraph: The flow conditions, as noted in the Review Report, are constant for each Monte Carlo simulation. The uncertainty in the calibrated flow fields, recharge, boundary conditions and stratigraphic framework are assessed through assembling matrices of Monte Carlo transport simulations. Parametric uncertainty for the calibrated flow fields is conducted using PESTbased null space Monte Carlo simulations. 
3. Page 7, last paragraph; Page 8 first three paragraphs: The Frenchman Flat transport model (Reference 12) evaluates the probability of exceeding SDWA requirements for all aquifers including the LCA. The UGTA strategy assumes public exposure could occur for any of the aquifers (alluvial, volcanic and LCA) and the long-range strategy includes restriction of public access to all aquifers contaminated above the SDWA through existing institutional controls for areas on the NTS and land use restrictions for areas outside the NTS boundaries.

4. Page 9, last paragraph: Twenty-five radionuclides are used in the transport simulations to calculate contaminant boundaries (Reference 12; page 7-2). The transport report describes 9 radionuclides not addressed by the SDWA requirements and these radionuclides represent about 0.1 percent of the Frenchman Flat inventory. Uncertainty analysis including identification of radionuclides controlling exceedence of the requirements of the SDWA are identified in the transport document (Reference 12; tritium, 14-C, 129-I, 36-Cl, 99-TC). These radionuclides are covered under the requirements of the SDWA.

5. Page 11, first full paragraph: The needs of all stakeholders will be met through the full UGTA strategy (four stages). The review questions given to the Review Panel are concerned with whether there is sufficient confidence in the data and transport model results to move to the CADD/CAP stage of the UGTA strategy. This requires, as stated in the UGTA strategy, that the model results are acceptable by the NDEP as a decision tool for making regulatory decisions. The model will continue to be refined through the CADD/CAP and CR stages and can be supplemented, as noted by the Review Panel, by auxiliary scenario/dose-exposure calculations in addition to the SDWA contaminant boundary forecasts.

6. Page 11, last paragraph: The calculations used to assess ensembles of contaminant boundary forecasts (Reference 12) include radionuclide concentrations in all aquifers (including the LCA), whether on or off the NTS.

7. Page 16; last paragraph: Multiple components of uncertainty (variability, parameter, model and framework uncertainty) are included in the ensemble of contaminant boundary forecasts as described in comment 1 of the Specific UGTA Subproject Clarifications/Corrections. 


\section{DISTRIBUTION}

\section{$\underline{\text { Copies }}$}

W.R. Wilborn

Environmental Restoration Project

U.S. Department of Energy

National Nuclear Security Administration

Nevada Site Office

P.O. Box 98518, M/S 505

Las Vegas, NV 89193-8518

K.C. Thompson

Environmental Restoration Project

U.S. Department of Energy

National Nuclear Security Administration

Nevada Site Office

P.O. Box 98518, M/S 505

Las Vegas, NV 89193-8518

Bimal Mukhopadhyay

Environmental Restoration Project

U.S. Department of Energy

National Nuclear Security Administration

Nevada Site Office

P.O. Box 98518, M/S 505

Las Vegas, NV 89193-8518

EM Records

U.S. Department of Energy

National Nuclear Security Administration

Nevada Site Office

P.O. Box 98518, M/S 505

Las Vegas, NV 89193-8518

NNSA/NSO, Read File

U.S. Department of Energy

National Nuclear Security Administration

Nevada Site Office

P.O. Box 98518, M/S NSF 161

Las Vegas, NV 89193-8518
2 hard copies w/2 electronic media

1 electronic media

1 hard copy w/electronic media

1 hard copy w/electronic media

1 hard copy w/electronic media 


\section{$\underline{\text { Copies }}$}

Charles Russell

Desert Research Institute

1 hard copy w/electronic media

755 E. Flamingo, M/S 433

Las Vegas, NV 89132-0040

Walt McNab

Lawrence Livermore National Laboratory

1 hard copy w/electronic media

7000 East Avenue, L-231

Livermore, CA 94550

Gayle Pawloski

Lawrence Livermore National Laboratory

7000 East Avenue, L-231

Livermore, CA 94550

Naomi Becker

Los Alamos National Laboratory

Hydrology, Geochemistry, and Geology Group, EES-6

Earth and Environmental Sciences Division

SM-30 Bikini Atoll Rd., MS F665

Los Alamos, NM 87545

Ed Kwicklis

Los Alamos National Laboratory

Hydrology, Geochemistry, and Geology Group, EES-6

Earth and Environmental Sciences Division

SM-30 Bikini Atoll Rd., MS T003

Los Alamos, NM 87545

Ken Ortego

National Security Technologies, LLC

1 hard copy w/electronic media

P.O. Box 98521 MS/NLV 082

Las Vegas, NV 89193

Bonnie Thompson

U.S. Geologic Survey WRD

1 hard copy w/electronic media

160 N. Stephanie St.

Henderson, NV 89074

Sam Marutzky

Navarro-Intera, LLC

1 hard copy w/electronic media

1 hard copy w/electronic media

P.O. Box 98952, NSF 167

Las Vegas, NV 89193-8518

1 hard copy w/electronic media 


\section{$\underline{\text { Copies }}$}

Bruce Crowe

Navarro-Intera, LLC

P.O. Box 98952, NSF 505

Las Vegas, NV 89193-8952

Greg Ruskauff

Navarro-Intera, LLC

P.O. Box 98952, NSF 167

Las Vegas, NV 89193-8952

Navarro-Intera, LLC

Central Files

P.O. Box 98952, NSF 156

Las Vegas, NV 89193-8518
1 hard copy w/electronic media

1 hard copy w/electronic media

1 hard copy w/electronic media 